\title{
LEVEL II SCOUR ANALYSIS FOR BRIDGE 52 (STOWTH00230052) on TOWN HIGHWAY 23, crossing the WEST BRANCH LITTLE RIVER, STOWE, VERMONT
}

\section{Open-File Report 98-061}

Prepared in cooperation with

VERMONT AGENCY OF TRANSPORTATION

and

FEDERAL HIGHWAY ADMINISTRATION

U.S. Department of the Interior

U.S. Geological Survey

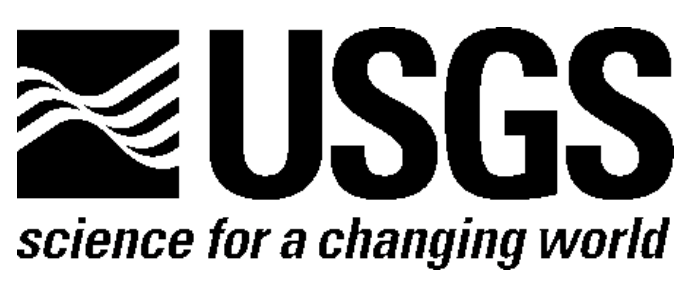




\section{LEVEL II SCOUR ANALYSIS FOR BRIDGE 52 (STOWTH00230052) on TOWN HIGHWAY 23, crossing the WEST BRANCH LITTLE RIVER, STOWE, VERMONT \\ By LORA K. STRIKER AND LAURA MEDALIE}

U.S. Geological Survey Open-File Report 98-061

Prepared in cooperation with

VERMONT AGENCY OF TRANSPORTATION and

FEDERAL HIGHWAY ADMINISTRATION 


\title{
U.S. DEPARTMENT OF THE INTERIOR BRUCE BABBITT, Secretary
}

\author{
U.S. GEOLOGICAL SURVEY
}

Thomas J. Casadevall, Acting Director

For additional information write to:

District Chief

U.S. Geological Survey 361 Commerce Way

Pembroke, NH 03275-3718
Copies of this report may be purchased from:

U.S. Geological Survey

Branch of Information Services

Open-File Reports Unit

Box 25286

Denver, CO 80225-0286 


\section{CONTENTS}

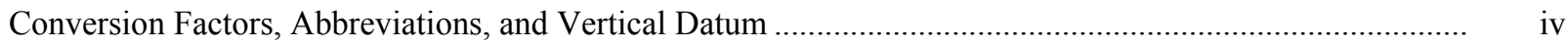

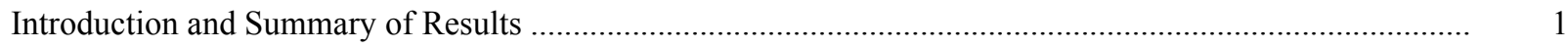

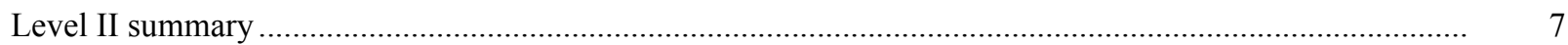

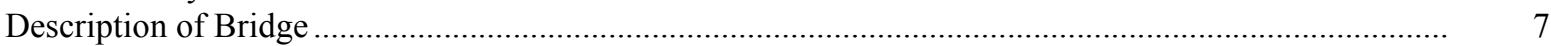

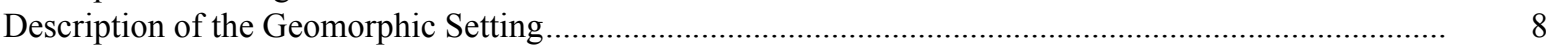

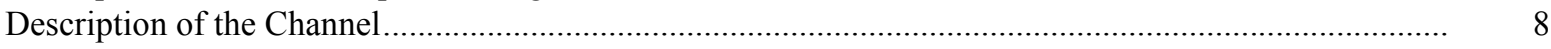

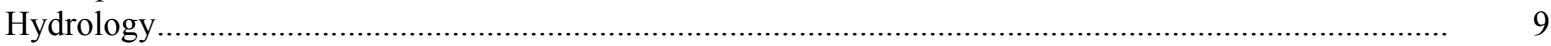

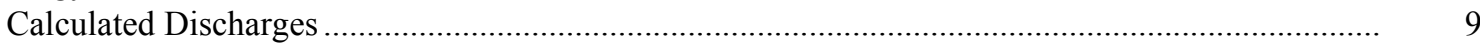

Description of the Water-Surface Profile Model (WSPRO) Analysis .................................................... 10

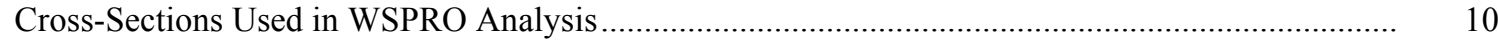

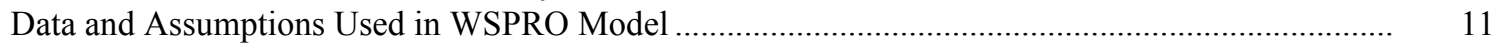

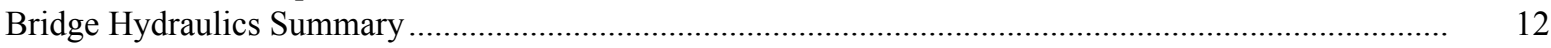

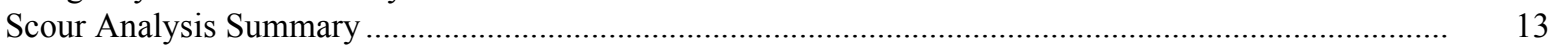

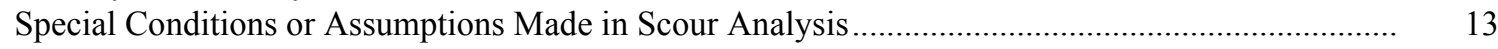

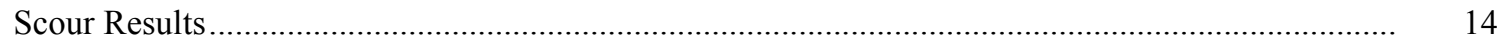

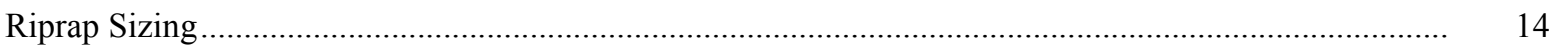

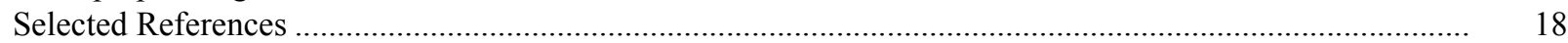

Appendices:

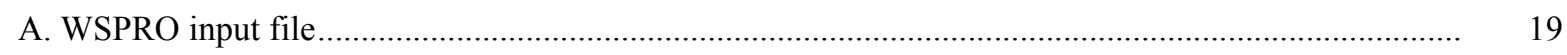

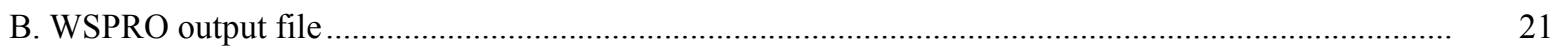

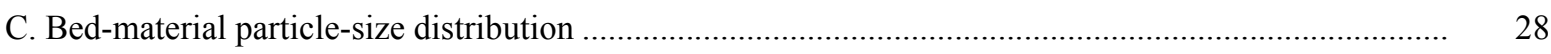

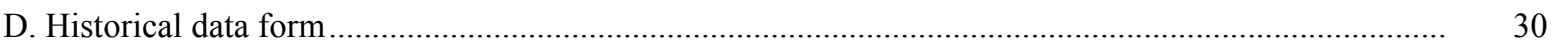

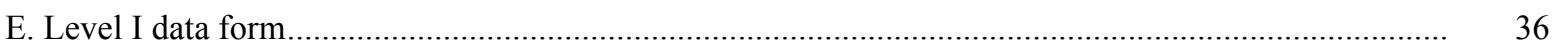

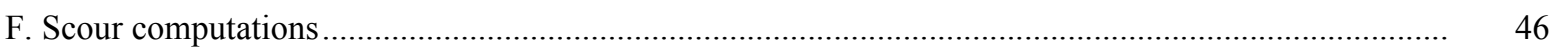

\section{FIGURES}

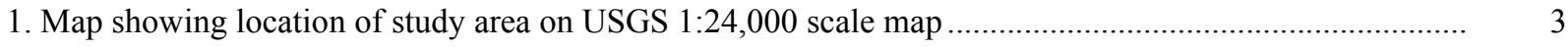

2. Map showing location of study area on Vermont Agency of Transportation town

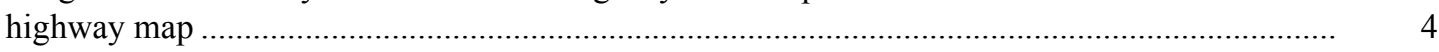

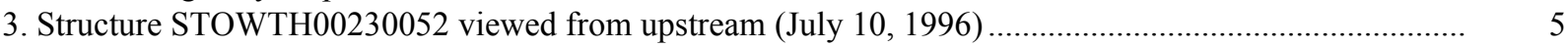

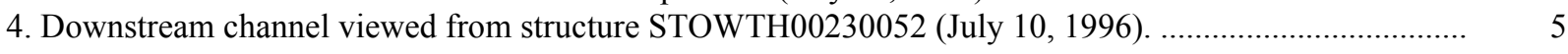

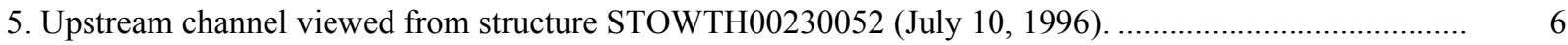

6. Structure STOWTH00230052 viewed from downstream (July 10, 1996)............................................... 6

7. Water-surface profiles for the 100- and 500-year discharges at structure

STOWTH00230052 on Town Highway 23, crossing the West Branch Little River, Stowe, Vermont.

8. Scour elevations for the 100- and 500-year discharges at structure

STOWTH00230052 on Town Highway 23, crossing the West Branch Little River,

Stowe, Vermont.

\section{TABLES}

1. Remaining footing/pile depth at abutments for the 100-year discharge at structure STOWTH00230052 on Town Highway 23, crossing the West Branch Little River,

Stowe, Vermont

2. Remaining footing/pile depth at abutments for the 500-year discharge at structure

STOWTH00230052 on Town Highway 23, crossing the West Branch Little River,

Stowe, Vermont 


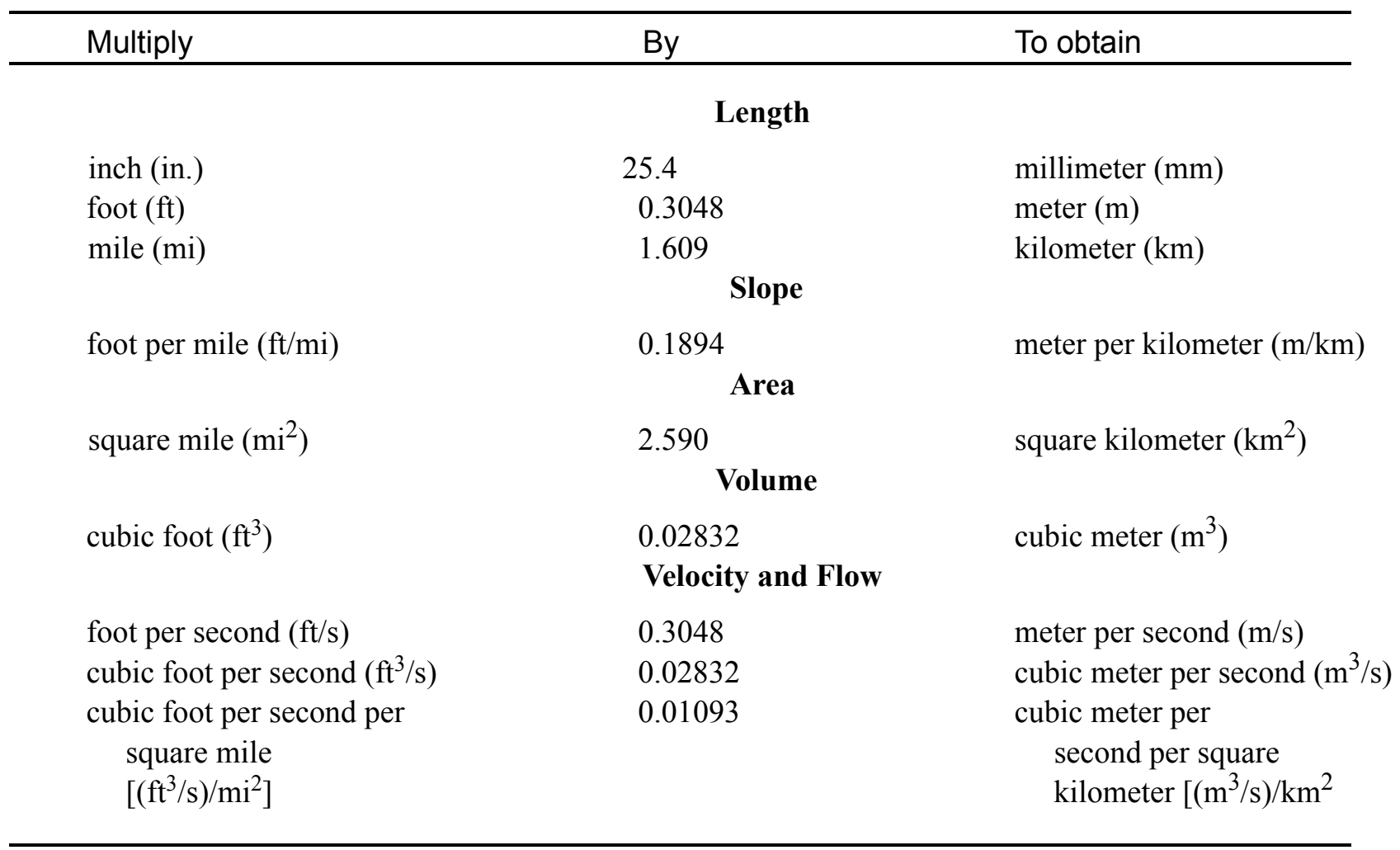

\section{OTHER ABBREVIATIONS}

$\begin{array}{lrlr}\mathrm{BF} & \text { bank full } & \text { LWW } & \text { left wingwall } \\ \mathrm{cfs} & \text { cubic feet per second } & \text { Max } & \text { maximum } \\ \mathrm{D}_{50} & \text { median diameter of bed material } & \text { MC } & \text { main channel } \\ \mathrm{DS} & \text { downstream } & \text { RAB } & \text { right abutment } \\ \mathrm{elev} & \text { elevation } & \text { RABUT } & \text { face of right abutment } \\ \mathrm{f} / \mathrm{p} & \text { flood plain } & \text { RB } & \text { right bank } \\ \mathrm{ft} & \text { square feet } & \text { ROB } & \text { right overbank } \\ \mathrm{ft} / \mathrm{ft} & \text { feet per foot } & \text { RWW } & \text { right wingwall } \\ \mathrm{FEMA} & \text { Federal Emergency Management Agency } & \text { TH } & \text { town highway } \\ \mathrm{FHWA} & \text { Federal Highway Administration } & \text { UB } & \text { under bridge } \\ \mathrm{JCT} & \text { junction } & \text { US } & \text { upstream } \\ \text { LAB } & \text { left abutment } & \text { USGS } & \text { United States Geological Survey } \\ \text { LABUT } & \text { face of left abutment } & \text { VTAOT } & \text { Vermont Agency of Transportation } \\ \text { LB } & \text { left bank } & \text { WSPRO } & \text { water-surface profile model } \\ \text { LOB } & \text { left overbank } & \text { yr } & \text { year }\end{array}$

In this report, the words "right" and "left" refer to directions that would be reported by an observer facing downstream. Sea level: In this report, "sea level" refers to the National Geodetic Vertical Datum of 1929-- a geodetic datum derived from a general adjustment of the first-order level nets of the United States and Canada, formerly called Sea Level Datum of 1929.

In the appendices, the above abbreviations may be combined. For example, USLB would represent upstream left bank. 


\title{
LEVEL II SCOUR ANALYSIS FOR BRIDGE 52 (STOWTH00230052) ON TOWN HIGHWAY 23, CROSSING THE WEST BRANCH LITTLE RIVER, STOWE, VERMONT
}

\author{
By Lora K. Striker and Laura Medalie
}

\section{INTRODUCTION AND SUMMARY OF RESULTS}

This report provides the results of a detailed Level II analysis of scour potential at structure STOWTH00230052 on Town Highway 23 crossing the West Branch Little River also referred to as the West Branch Waterbury River, Stowe, Vermont (figures 1-8). A Level II study is a basic engineering analysis of the site, including a quantitative analysis of stream stability and scour (FHWA, 1993). Results of a Level I scour investigation also are included in appendix $\mathrm{E}$ of this report. A Level I investigation provides a qualitative geomorphic characterization of the study site. Information on the bridge, gleaned from Vermont Agency of Transportation (VTAOT) files, was compiled prior to conducting Level I and Level II analyses and is found in appendix D.

The site is in the Green Mountain section of the New England physiographic province in north central Vermont. The $26.7-\mathrm{mi}^{2}$ drainage area is in a predominantly rural and forested basin. In the vicinity of the study site, the surface cover is predominantly pasture while the left bank upstream and downstream of the site is shrub and brushland.

In the study area, the West Branch Little River has a sinuous channel with irregular point and lateral bars and a slope of approximately $0.01 \mathrm{ft} / \mathrm{ft}$, an average channel top width of 110 $\mathrm{ft}$ and an average bank height of $11 \mathrm{ft}$. The channel bed material ranges from gravel to cobble with a median grain size $\left(\mathrm{D}_{50}\right)$ of $25.8 \mathrm{~mm}(0.085 \mathrm{ft})$. The geomorphic assessment at the time of the Level I and Level II site visit on

July 10, 1996, indicated that the reach was stable.

The Town Highway 23 crossing of the West Branch Little River is a 64-ft-long, two-lane bridge consisting of one 61-foot concrete span (Vermont Agency of Transportation, written communication, October 13, 1995). The opening length of the structure parallel to the bridge face is $59 \mathrm{ft}$. The bridge is supported by a vertical, mortared stone abutment on the left and a vertical, concrete abutment with wingwalls on the right. The channel is skewed approximately 15 degrees to the opening while the opening-skew-to-roadway is 0 degrees. 
A scour hole $3.0 \mathrm{ft}$ deeper than the mean thalweg depth was observed along the right bank upstream at a bend in the channel during the Level I assessment. The only scour protection measure at the site was type- 2 stone fill (less than 36 inches diameter) along the left and right banks upstream, along the left abutment, upstream end of the right abutment, upstream end of the downstream right wingwall, and along the left and right banks downstream; and type-3 stone fill (less than 48 inches diameter) along the base of the upstream right wingwall. Additional details describing conditions at the site are included in the Level II Summary and appendices D and E.

Scour depths and recommended rock rip-rap sizes were computed using the general guidelines described in Hydraulic Engineering Circular 18 (Richardson and Davis, 1995) for the 100- and 500-year discharges. In addition, the incipient roadway-overtopping discharge was determined and analyzed as another potential worst-case scour scenario. Total scour at a highway crossing is comprised of three components: 1) long-term streambed degradation; 2) contraction scour (due to accelerated flow caused by a reduction in flow area at a bridge) and; 3 ) local scour (caused by accelerated flow around piers and abutments). Total scour is the sum of the three components. Equations are available to compute depths for contraction and local scour and a summary of the results of these computations follows.

Contraction scour for all modelled flows ranged from 2.7 to $3.9 \mathrm{ft}$. The worst-case contraction scour occurred at the 500-year discharge. Left abutment scour ranged from 11.4 to $13.1 \mathrm{ft}$ and right abutment scour ranged from 7.0 to $11.0 \mathrm{ft}$. The worst-case abutment scour occurred at the 500-year discharge. Additional information on scour depths and depths to armoring are included in the section titled "Scour Results". Scoured-streambed elevations, based on the calculated scour depths, are presented in tables 1 and 2. A crosssection of the scour computed at the bridge is presented in figure 8. Scour depths were calculated assuming an infinite depth of erosive material and a homogeneous particle-size distribution.

It is generally accepted that the Froehlich equation (abutment scour) gives "excessively conservative estimates of scour depths" (Richardson and Davis, 1995, p. 47). Usually, computed scour depths are evaluated in combination with other information including (but not limited to) historical performance during flood events, the geomorphic stability assessment, existing scour protection measures, and the results of the hydraulic analyses. Therefore, scour depths adopted by VTAOT may differ from the computed values documented herein. 


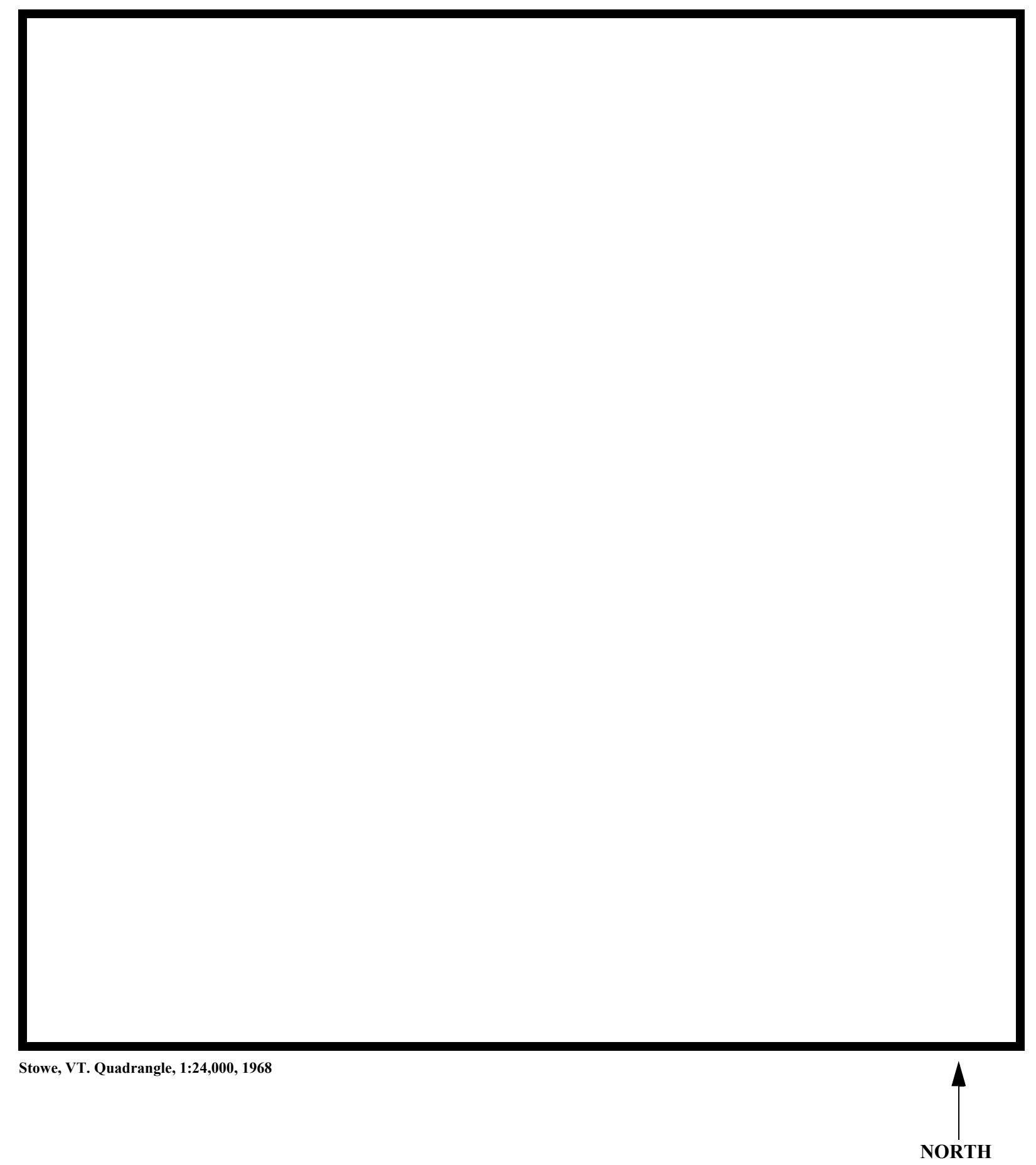

Figure 1. Location of study area on USGS 1:24,000 scale map. 
Figure 2. Location of study area on Vermont Agency of Transportation town highway map. 

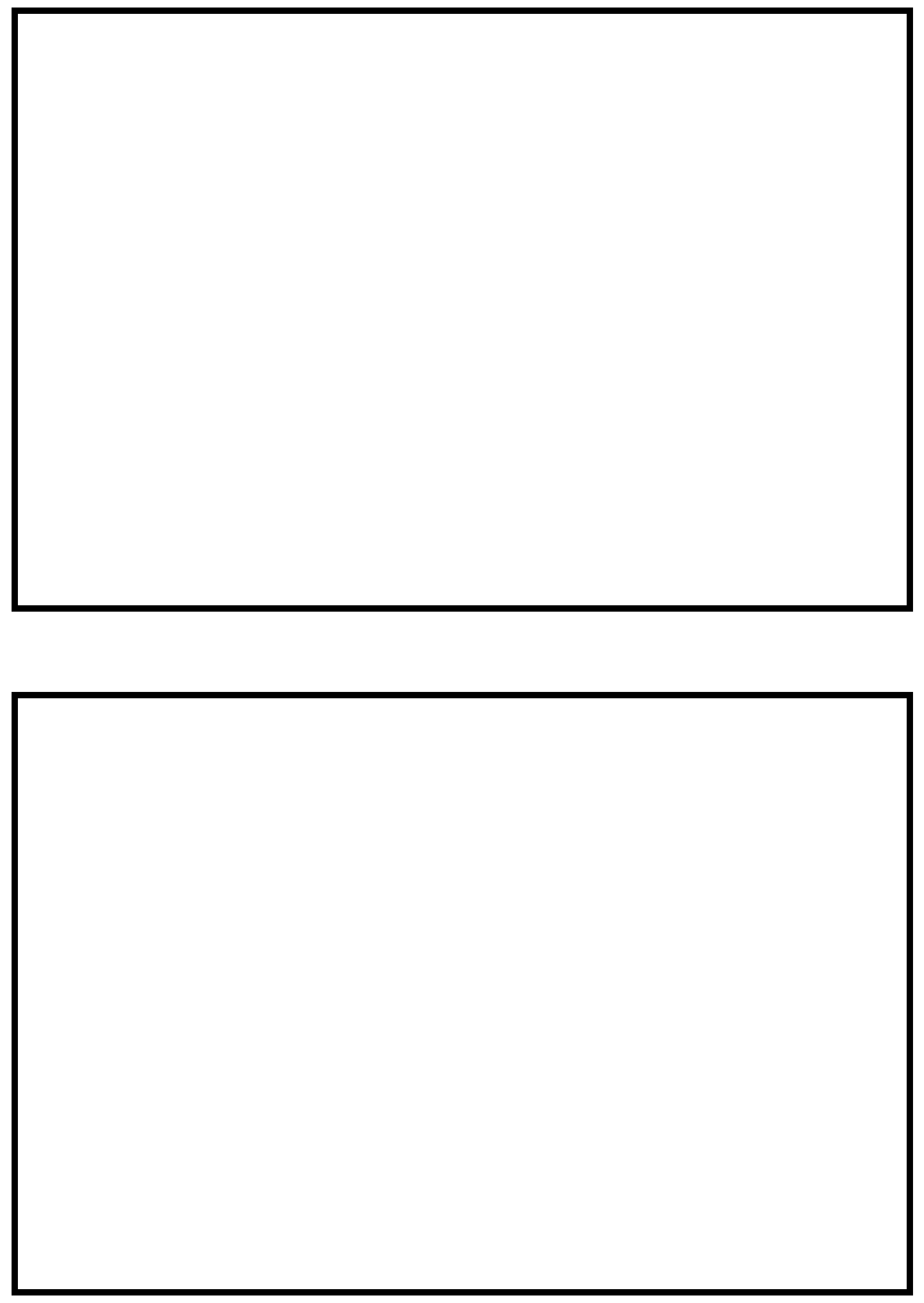

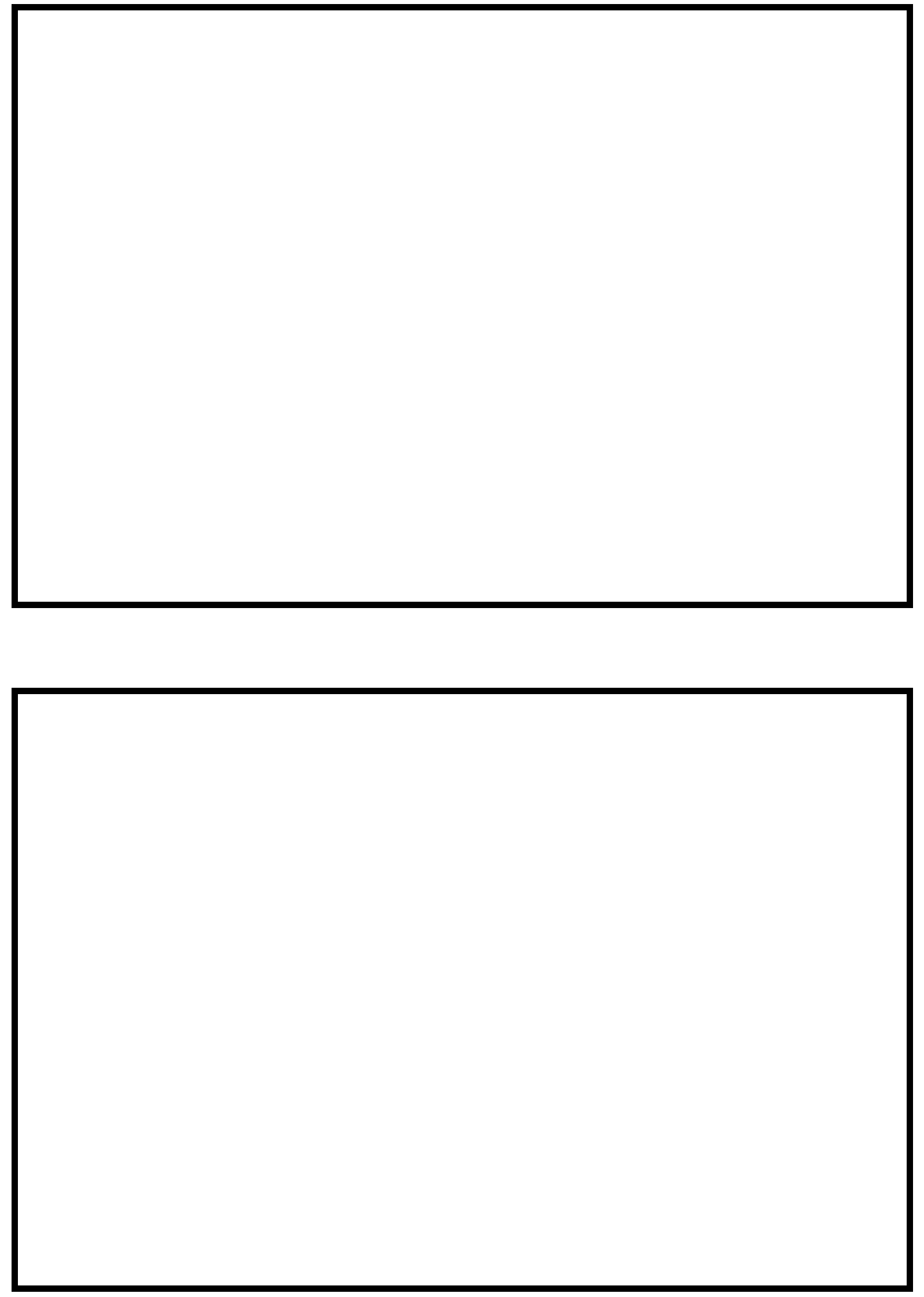


\section{LEVEL II SUMMARY}

\begin{tabular}{llllll} 
Structure Number & STOWTH00230052 & \multirow{2}{*}{ Stream } & \multicolumn{2}{c}{ West Branch Little River } \\
& Lounty & Lamoille & TH23 & District & 6
\end{tabular}

\section{Description of Bridge}

Bridge length $\frac{64}{2} f t \quad$ Bridge width $\frac{25.6}{f t}$ Max span length $\frac{61}{f t}$ Alignment of bridge to road (on curve or straight)

Abutment type Vertical

Stone fill on abutment?

$$
\text { Yes }
$$

\section{Embankment type} Curve

Drto of incnortion Type-2, along the base of the left abutment, upstream end of the right
Sloping; near vertical

\section{$07 / 10 / 96$}

DS RWW are concrete. The RABUT concrete footing is exposed, and has wooden sheeting along the base of the footing. The sheeting is undermined at the US end.

$$
\text { Yes }
$$$$
\text { Angle }
$$ \\ Is bridge skewed to flood flow according to Yes 'survey? Angle}

There is a mild_channel bend in the upstream reach._A_sçour hole has developed in the location where the bend impacts the right bank upstream.

\begin{tabular}{|c|c|c|c|}
\hline & $\begin{array}{c}\text { Date of insmortion } \\
07 / 10 / 96 \\
\end{array}$ & $\begin{array}{l}\text { Percent of alommal } \\
\text { blocked inortzontatly }\end{array}$ & $\begin{array}{l}\text { Percent of } 0 \\
\text { blocked verticatty }\end{array}$ \\
\hline & $07 / 10 / 96$ & 0 & 0 \\
\hline & Low. & & \\
\hline
\end{tabular}

Debris accumulation on bridge at time of Level I or Level II site visit:

\section{Potential for debris}

None, 07/10/96.

Doscriho anv, foaturos noar ar at tho hridoo that mav, affort flou, (includo ahsorvation dato). 


\section{Description of the Geomorphic Setting}

General topography The channel is located within a moderate relief valley, with a wide flood plain.

Geomorphic conditions at bridge site: downstream (DS), upstream (US)

Date of inspection $\quad 07 / 10 / 96$

DS left: $\quad$ Steep channel bank to moderately sloped overbank

DS right: $\quad$ Steep channel bank to a wide flood plain

US left: $\quad$ Steep channel bank to a wide flood plain

US right: $\quad$ Steep channel bank to a wide flood plain

\section{Description of the Channel}

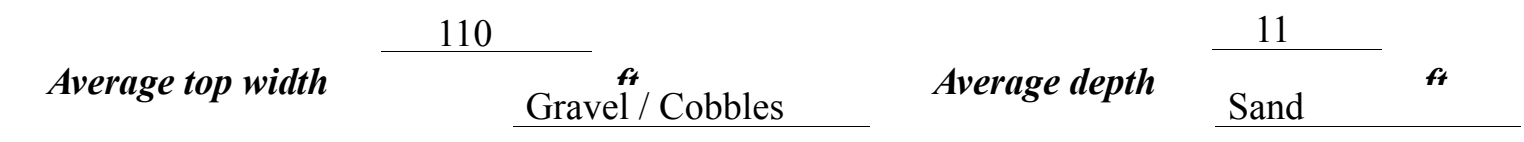

Predominant bed material

Bank material Sinuous but stable

with alluvial channel boundaries and a wide flood plain.

$07 / 10 / 96$

Vegetative co 1 Brush, shrubs, and a few trees

DS left: $\quad$ Brush and trees with a pasture overbank

DS right: $\quad$ Brush and a few trees

US left: $\quad$ Brush and a few trees with a pasture overbank

US right: $\quad$ Yes

Do banks appear stable? Banks appear stable, however, a cut-bank has developed along the dright bank upstream.

None, 07/10/96.

Describe any obstructions in channel and date of observation. 


\section{Hydrology}

Drainage area $\stackrel{26.7}{2} \boldsymbol{m i}^{2}$

Percentage of drainage area in physiographic provinces: (approximate)

Physiographic province/section

New England/Green Mountain
Percent of drainage area 100

Is drainage area considered rural or urban? — Rural _ Describe any significant urbanization:

Yes

Is there a USGS gage on the stream of interest? Little River near Waterbury, VT

USGS gage description 04289000

USGS gage number

Gage drainage area $\mathrm{mi}^{2}$ No

Is there a lake/p Records are available from $1935^{\circ}$ to present. Flow hä been regulated by Waterbury Reservoir since 1937. The bridge is upstream of any regulation.

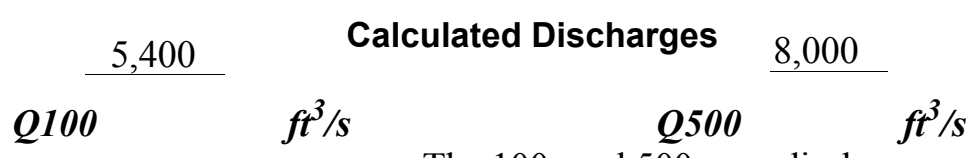

The 100- and 500-year discharges are based on a

drainage area relationship.[(26.7/23.8)exp 0.67] with bridge number 3 in Stowe. Bridge number 3 crosses the West Branch Little River upstream of this site and has flood frequency estimates available from the VTAOT database. The drainage area above bridge number 3 is 23.8 square miles. The values used were within a range defined by flood frequency curves developed from several empirical methods (Benson, 1962; Johnson and Tasker, 1974; FHWA, 1983; Potter, 1957a\&b; Talbot, 1887). 


\section{Description of the Water-Surface Profile Model (WSPRO) Analysis}

Datum for WSPRO analysis (USGS survey, sea level, VTAOT plans)

USGS survey

Datum tie between USGS survey and VTAOT plans

None.

Description of reference marks used to determine USGS datum. $\quad$ RM1 is center of

chiseled square at DS end of the right abutment (elev. $500.67 \mathrm{ft}$, arbitrary survey datum). RM2 is

a chiseled X on US end of the left abutment (elev. $500.29 \mathrm{ft}$, arbitrary survey datum). RM3 is a

spike in pole $2.5 \mathrm{ft}$ high on DS left bank $20 \mathrm{ft}$ DS and $20 \mathrm{ft} \mathrm{LB}$ from DS end of the left abutment

(elev. $497.45 \mathrm{ft}$, arbitrary survey datum).

\section{Cross-Sections Used in WSPRO Analysis}

\begin{tabular}{cccl}
\hline${ }^{1}$ Cross-section & $\begin{array}{c}\text { Section } \\
\text { Reference } \\
\text { Distance } \\
(\text { SRD) } \text { in feet }\end{array}$ & $\begin{array}{c}{ }^{2} \text { Cross-section } \\
\text { development }\end{array}$ & \multicolumn{1}{c}{ Comments } \\
\hline EXITX & -58 & 1 & Exit section \\
FULLV & 0 & 2 & $\begin{array}{l}\text { Downstream Full-valley } \\
\text { section (Templated from } \\
\text { EXITX) }\end{array}$ \\
BRIDG & 0 & 1 & $\begin{array}{l}\text { Bridge section } \\
\text { Road Grade section } \\
\text { RDWAY }\end{array}$ \\
APPRO & 13 & 1 & $\begin{array}{l}\text { Approach section (as sur- } \\
\text { veyed) }\end{array}$ \\
\hline
\end{tabular}

${ }^{1}$ For location of cross-sections see plan-view sketch included with Level I field form, Appendix E. For more detail on how cross-sections were developed see WSPRO input file. 


\section{Data and Assumptions Used in WSPRO Model}

Hydraulic analyses of the reach were done by use of the Federal Highway Administration's WSPRO step-backwater computer program (Shearman and others, 1986, and Shearman, 1990). The analyses reported herein reflect conditions existing at the site at the time of the study. Furthermore, in the development of the model it was necessary to assume no accumulation of debris or ice at the site. Results of the hydraulic model are presented in the Bridge Hydraulic Summary, appendix B, and figure 7.

Channel roughness factors (Manning's “ $n$ ”) used in the hydraulic model were estimated using field inspections at each cross section following the general guidelines described by Arcement and Schneider (1989). Final adjustments to the values were made during the modelling of the reach. Channel " $\mathrm{n}$ " values for the reach ranged from 0.045 to 0.062 , and overbank " $\mathrm{n}$ " values ranged from 0.030 to 0.040 .

Normal depth at the exit section (EXITX) was assumed as the starting water surface. This depth was computed by use of the slope-conveyance method outlined in the user's manual for WSPRO (Shearman, 1990). The slope used was $0.0014 \mathrm{ft} / \mathrm{ft}$, which was taken from the 100year water surface profile below this site in the Flood Insurance Study (FIS) for the town of Stowe, VT (FEMA, 1980).

The approach section (APPRO) was surveyed one bridge length upstream of the upstream face as recommended by Shearman and others (1986). This location provides a consistent method for determining scour variables. 


\section{Bridge Hydraulics Summary}

$\begin{array}{llll}\text { Average bridge embankment elevation } & 500.6 & f t \\ \text { Average low steel elevation } & 497.4 & \boldsymbol{f t}\end{array}$

100-year discharge $\quad 5,400 \quad \mathrm{ft}^{3} / \mathrm{s}$

Water-surface elevation in bridge opening $\quad 491.8 \quad f t$

Road overtopping? ___ No Discharge over road ___ - $\mathrm{ft}^{3} / \mathrm{s}$

Area of flow in bridge opening $\quad 512 \quad \mathrm{ft}^{2}$

Average velocity in bridge opening $10.6 \mathrm{ft} / \mathrm{s}$

Maximum WSPRO tube velocity at bridge $\quad 13.7 \mathrm{ft} / \mathrm{s}$

Water-surface elevation at Approach section with bridge

494.2

Water-surface elevation at Approach section without bridge

Amount of backwater caused by bridge

$2.0 \quad$ it

500-year discharge $\quad 8,000 \quad \mathrm{ft}^{3} / \mathrm{s}$

Water-surface elevation in bridge opening

$493.0 \mathrm{ft}$

Road overtopping? ___ Yes Discharge over road __ 1,310 $\mathrm{ft}^{3} / \mathrm{s}$

Area of flow in bridge opening $\quad 579 \quad \mathrm{ft}^{2}$

Average velocity in bridge opening $11.6 \mathrm{ft} / \mathrm{s}$

Maximum WSPRO tube velocity at bridge 15.2 , 's

Water-surface elevation at Approach section with bridge 496.0

Water-surface elevation at Approach section without bridge $\quad 493.3$

Amount of backwater caused by bridge $\quad 2.7, t$

Incipient overtopping discharge $\quad 6,040 \mathrm{ft}^{3} / \mathrm{s}$

Water-surface elevation in bridge opening 491.9 t

Area of flow in bridge opening $\quad 518 \quad \mathrm{ft}^{2}$

Average velocity in bridge opening $\quad 11.7 \quad \mathrm{ft} / \mathrm{s}$

Maximum WSPRO tube velocity at bridge $\quad 15.2 \quad \mathrm{ft} / \mathrm{s}$

Water-surface elevation at Approach section with bridge

Water-surface elevation at Approach section without bridge

494.8

Amount of backwater caused by bridge $\quad 2.4$, t 


\section{Scour Analysis Summary}

\section{Special Conditions or Assumptions Made in Scour Analysis}

Scour depths were computed using the general guidelines described in Hydraulic Engineering Circular 18 (Richardson and Davis, 1995). Scour depths were calculated assuming an infinite depth of erosive material and a homogeneous particle-size distribution. The results of the scour analysis are presented in tables 1 and 2 and a graph of the scour depths is presented in figure 8.

Contraction scour was computed by the Laursen clear-water contraction scour equation (Richardson and Davis, 1995, p. 32, equation 20). Variables for the Laursen clearwater contraction scour equation include the discharge through the bridge, the width of the channel at the bridge, and the median grain size of the channel bed material.

Left abutment scour was computed by use of the Froehlich equation (Richardson and Davis, 1995, p. 48, equation 28). Variables for the Froehlich equation include the Froude number of the flow approaching the embankments, the length of the embankment blocking flow, and the depth of flow approaching the embankment less any roadway overtopping.

Scour at the right abutment was computed by use of the HIRE equation (Richardson and Davis, 1995, p. 49, equation 29) because the HIRE equation is recommended when the length to depth ratio of the embankment blocking flow exceeds 25 . The variables used by the HIRE abutment-scour equation are defined the same as those defined for the Froehlich abutment-scour equation. 


\section{Scour Results}

$$
\text { 100-yr discharge 500-yrdischarge }
$$

(Scour depths in feet)

Main channel

Live-bed scour

Clear-water scour

Depth to armoring

Left overbank

Right overbank

Local scour:

Abutment scour

Left abutment

Right abutment

Pier scour

Pier 1

Pier 2

Pier 3
11.4

7.0-
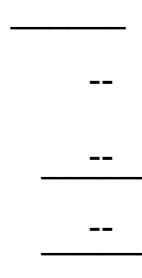

13.1

11.0
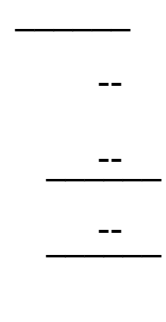
discharge

Incipient 


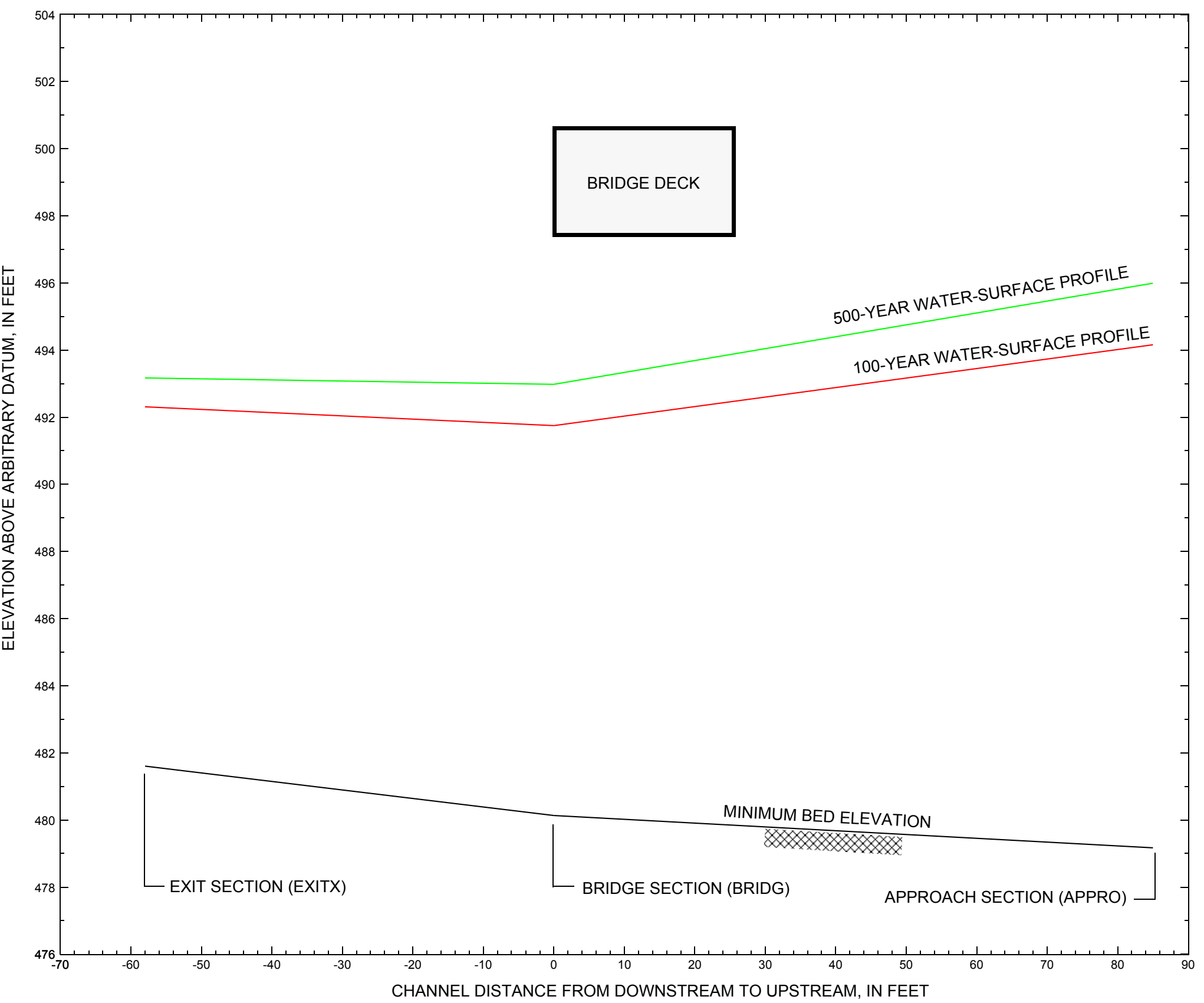

Figure 7. Water-surface profiles for the 100- and 500-year discharges at structure STOWTH00230052 on Town Highway 23, crossing the West Branch Little River, Stowe, Vermont. 


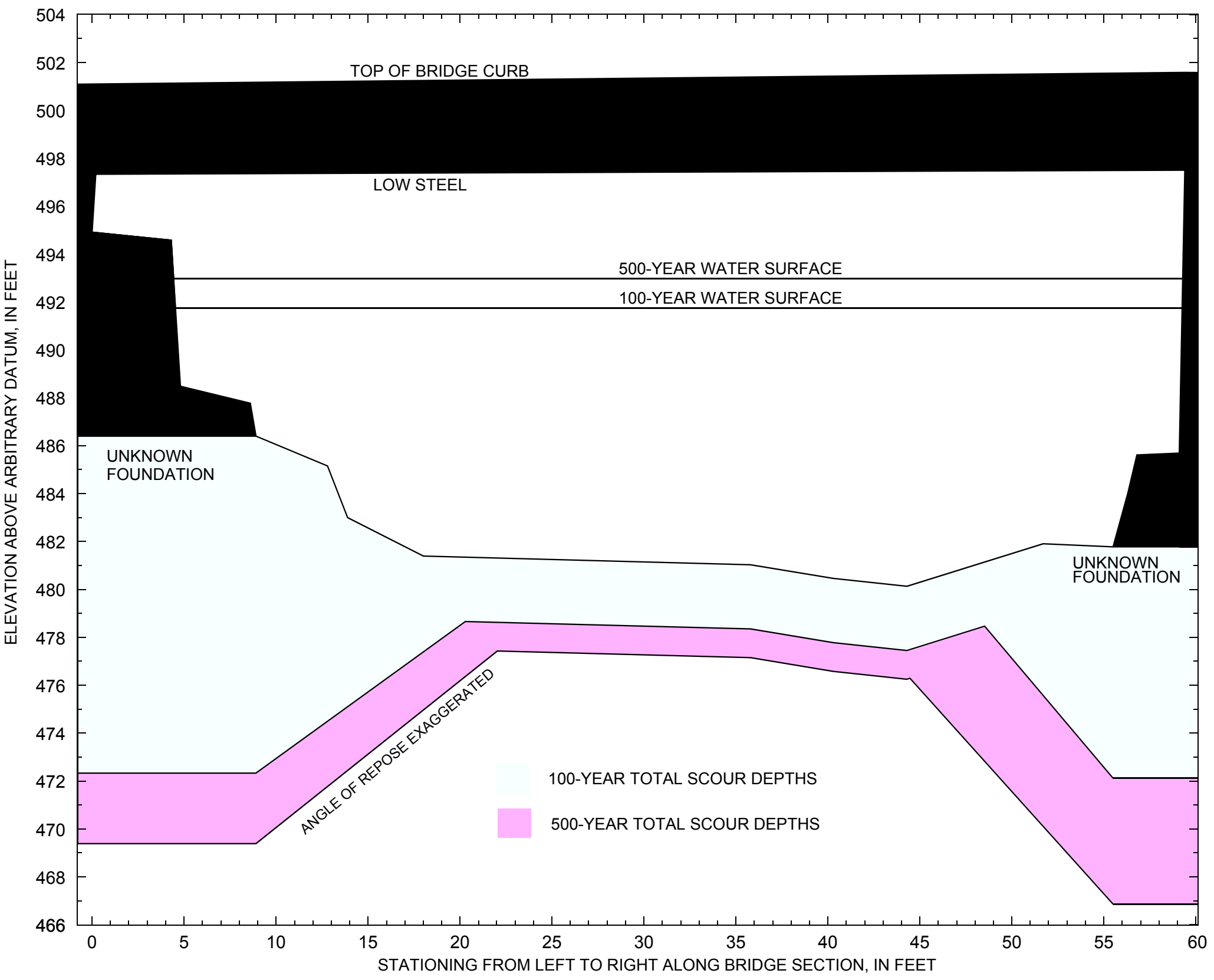

Figure 8. Scour elevations for the 100- and 500-year discharges at structure STOWTH00230052 on Town Highway 23, crossing the West Branch Little River, Stowe, Vermont. 
Table 1. Remaining footing/pile depth at abutments for the 100-year discharge at structure STOWTH00230052 on Town Highway 23, crossing the West Branch Little River, Stowe, Vermont.

[VTAOT, Vermont Agency of Transportation; --,no data]

\begin{tabular}{|c|c|c|c|c|c|c|c|c|c|c|c|}
\hline Description & Station $^{1}$ & $\begin{array}{l}\text { VTAOT } \\
\text { minimum } \\
\text { low-chord } \\
\text { elevation } \\
\text { (feet) }\end{array}$ & $\begin{array}{c}\text { Surveyed } \\
\text { minimum } \\
\text { low-chord } \\
\text { elevation } \\
\text { (feet) }\end{array}$ & $\begin{array}{c}\text { Bottom of } \\
\text { footing/pile } \\
\text { elevation } \\
\text { (feet) }\end{array}$ & $\begin{array}{l}\text { Channel } \\
\text { elevation at } \\
\text { abutment/ } \\
\text { pier }^{2} \\
\text { (feet) }\end{array}$ & $\begin{array}{l}\text { Contraction } \\
\text { scour depth } \\
\text { (feet) }\end{array}$ & $\begin{array}{l}\text { Abutment } \\
\text { scour } \\
\text { depth } \\
\text { (feet) }\end{array}$ & $\begin{array}{l}\text { Pier } \\
\text { scour } \\
\text { depth } \\
\text { (feet) }\end{array}$ & $\begin{array}{l}\text { Depth of } \\
\text { total scour } \\
\text { (feet) }\end{array}$ & $\begin{array}{c}\text { Elevation of } \\
\text { scour }^{2} \\
\text { (feet) }\end{array}$ & $\begin{array}{c}\text { Remaining } \\
\text { footing/pile } \\
\text { depth } \\
\text { (feet) }\end{array}$ \\
\hline \multicolumn{12}{|c|}{100 -year discharge is 5,400 cubic-feet per second } \\
\hline Left abutment & 0.0 & -- & 497.3 & -- & 486.4 & 2.7 & 11.4 & -- & 14.1 & 472.3 & -- \\
\hline Right abutment & 59.4 & -- & 497.5 & -- & 481.8 & 2.7 & 7.0 & -- & 9.7 & 472.1 & -- \\
\hline
\end{tabular}

1.Measured along the face of the most constricting side of the bridge.

2.Arbitrary datum for this study.

Table 2. Remaining footing/pile depth at abutments for the 500-year discharge at structure STOWTH00230052 on Town Highway 23, crossing the West Branch Little River, Stowe, Vermont.

[VTAOT, Vermont Agency of Transportation; --, no data]

\begin{tabular}{|c|c|c|c|c|c|c|c|c|c|c|c|}
\hline Description & Station $^{1}$ & $\begin{array}{l}\text { VTAOT } \\
\text { minimum } \\
\text { low-chord } \\
\text { elevation } \\
\text { (feet) }\end{array}$ & $\begin{array}{c}\text { Surveyed } \\
\text { minimum } \\
\text { low-chord } \\
\text { elevation } \\
\text { (feet) }\end{array}$ & $\begin{array}{c}\text { Bottom of } \\
\text { footing/pile } \\
\text { elevation } \\
\text { (feet) }\end{array}$ & $\begin{array}{c}\text { Channel } \\
\text { elevation at } \\
\text { abutment/ } \\
\text { pier }^{2} \\
\text { (feet) }\end{array}$ & $\begin{array}{l}\text { Contraction } \\
\text { scour depth } \\
\text { (feet) }\end{array}$ & $\begin{array}{c}\text { Abutment } \\
\text { scour } \\
\text { depth } \\
\text { (feet) }\end{array}$ & $\begin{array}{l}\text { Pier } \\
\text { scour } \\
\text { depth } \\
\text { (feet) }\end{array}$ & $\begin{array}{l}\text { Depth of } \\
\text { total scour } \\
\text { (feet) }\end{array}$ & $\begin{array}{c}\text { Elevation of } \\
\text { scour }^{2} \\
\text { (feet) }\end{array}$ & $\begin{array}{c}\text { Remaining } \\
\text { footing/pile } \\
\text { depth } \\
\text { (feet) }\end{array}$ \\
\hline \multicolumn{12}{|c|}{500 -year discharge is 8,000 cubic-feet per second } \\
\hline Left abutment & 0.0 & -- & 497.3 & -- & 486.4 & 3.9 & 13.1 & -- & 17.0 & 469.4 & -- \\
\hline Right abutment & 59.4 & -- & 497.5 & -- & 481.8 & 3.9 & 11.0 & -- & 14.9 & 466.9 & -- \\
\hline
\end{tabular}

1.Measured along the face of the most constricting side of the bridge.

2.Arbitrary datum for this study. 


\section{SELECTED REFERENCES}

Arcement, G.J., Jr., and Schneider, V.R., 1989, Guide for selecting Manning's roughness coefficients for natural channels and flood plains: U.S. Geological Survey Water-Supply Paper 2339, 38 p.

Barnes, H.H., Jr., 1967, Roughness characteristics of natural channels: U.S. Geological Survey Water-Supply Paper 1849,213 p.

Benson, M. A., 1962, Factors Influencing the Occurrence of Floods in a Humid Region of Diverse Terrain: U.S. Geological Survey WaterSupply Paper 1580-B, 64 p.

Brown, S.A. and Clyde, E.S., 1989, Design of riprap revetment: Federal Highway Administration Hydraulic Engineering Circular No. 11, Publication FHWA-IP-89-016, 156 p.

Federal Highway Administration, 1983, Runoff estimates for small watersheds and development of sound design: Federal Highway Administration Report FHWA-RD-77-158.

Federal Highway Administration, 1993, Stream Stability and Scour at Highway Bridges: Participant Workbook: Federal Highway Administration Report FHWA-HI-91-011.

Federal Emergency Management Agency, 1980, Flood Insurance Study, Town of Stowe, Lamoille County, Vermont: Washington, D.C., January 1980.

Froehlich, D.C., 1989, Local scour at bridge abutments in Ports, M.A., ed., Hydraulic Engineering--Proceedings of the 1989 National Conference on Hydraulic Engineering: New York, American Society of Civil Engineers, p. 13-18.

Hayes, D.C.,1993, Site selection and collection of bridge-scour data in Delaware, Maryland, and Virginia: U.S. Geological Survey WaterResources Investigation Report 93-4017, 23 p.

Interagency Advisory Committee on Water Data, 1982, Guidelines for determining flood flow frequency: U.S. Geological Survey, Bulletin 17B of the Hydrology Subcommittee, 190 p.

Johnson, C.G. and Tasker, G.D.,1974, Progress report on flood magnitude and frequency of Vermont streams: U.S. Geological Survey OpenFile Report 74-130, 37 p.

Lagasse, P.F., Schall, J.D., Johnson, F., Richardson, E.V., Chang, F., 1995, Stream Stability at Highway Structures: Federal Highway Administration Hydraulic Engineering Circular No. 20, Publication FHWA-IP-90-014, 144 p.

Laursen, E.M., 1960, Scour at bridge crossings: Journal of the Hydraulics Division, American Society of Civil Engineers, v. 86, no. HY2, p. 39-53.

Potter, W. D., 1957a, Peak rates of runoff in the Adirondack, White Mountains, and Maine woods area, Bureau of Public Roads

Potter, W. D., 1957b, Peak rates of runoff in the New England Hill and Lowland area, Bureau of Public Roads

Richardson, E.V. and Davis, S.R., 1995, Evaluating scour at bridges: Federal Highway Administration Hydraulic Engineering Circular No. 18, Publication FHWA-IP-90-017, 204 p.

Richardson, E.V., Simons, D.B., and Julien, P.Y., 1990, Highways in the river environment: Federal Highway Administration Publication FHWA-HI-90-016.

Ritter, D.F., 1984, Process Geomorphology: W.C. Brown Co., Debuque, Iowa, 603 p.

Shearman, J.O., 1990, User's manual for WSPRO--a computer model for water surface profile computations: Federal Highway Administration Publication FHWA-IP-89-027, 187 p.

Shearman, J.O., Kirby, W.H., Schneider, V.R., and Flippo, H.N., 1986, Bridge waterways analysis model; research report: Federal Highway Administration Publication FHWA-RD-86-108, 112 p.

Talbot, A.N., 1887, The determination of water-way for bridges and culverts.

U.S. Geological Survey, 1968, Stowe, Vermont 7.5 Minute Series quadrangle map: U.S. Geological Survey Topographic Maps, Scale $1: 24,000$. 


\section{APPENDIX A: \\ WSPRO INPUT FILE}




\section{WSPRO INPUT FILE}

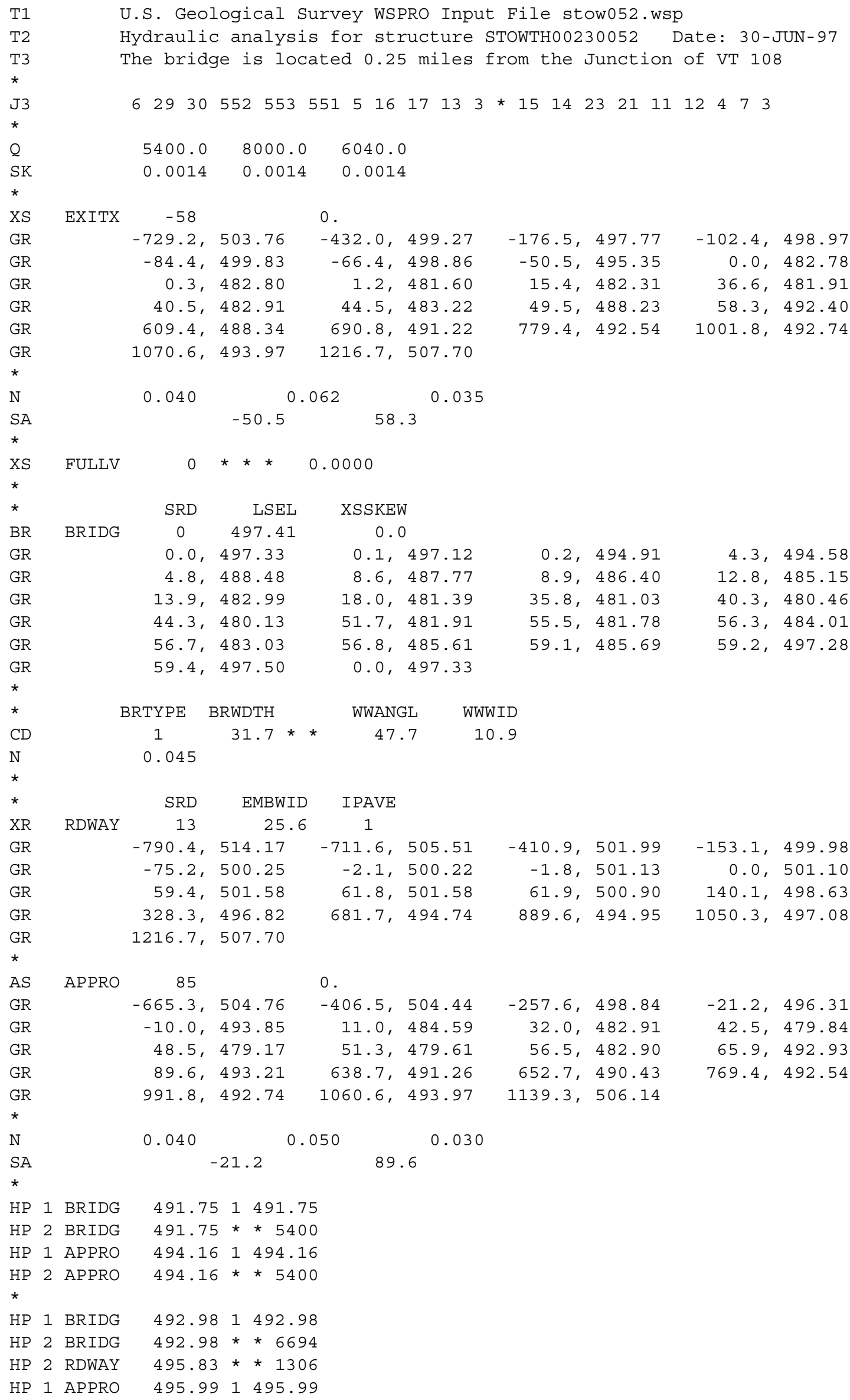




\section{APPENDIX B: \\ WSPRO OUTPUT FILE}




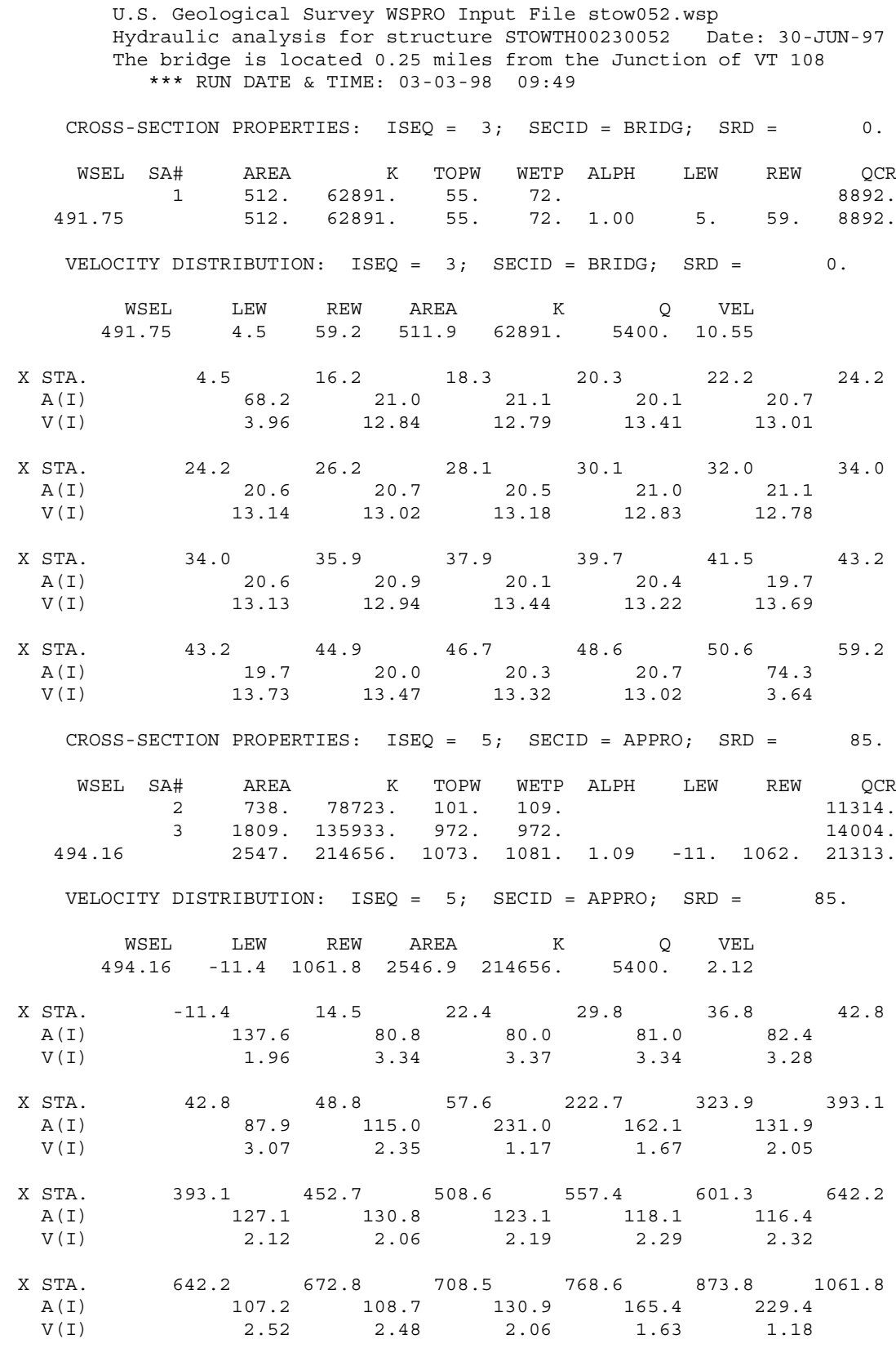




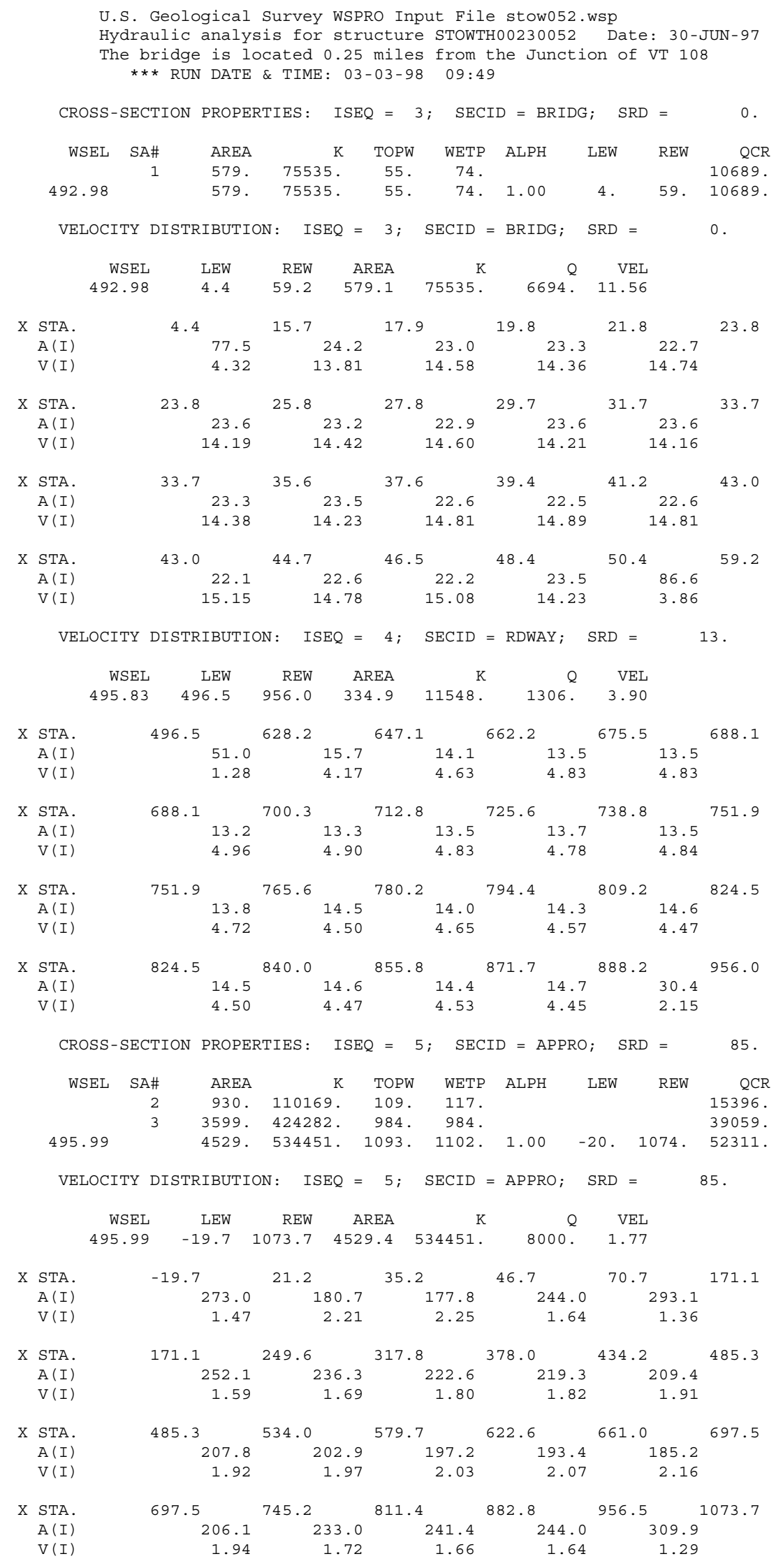


WSPRO OUTPUT FILE (continued)

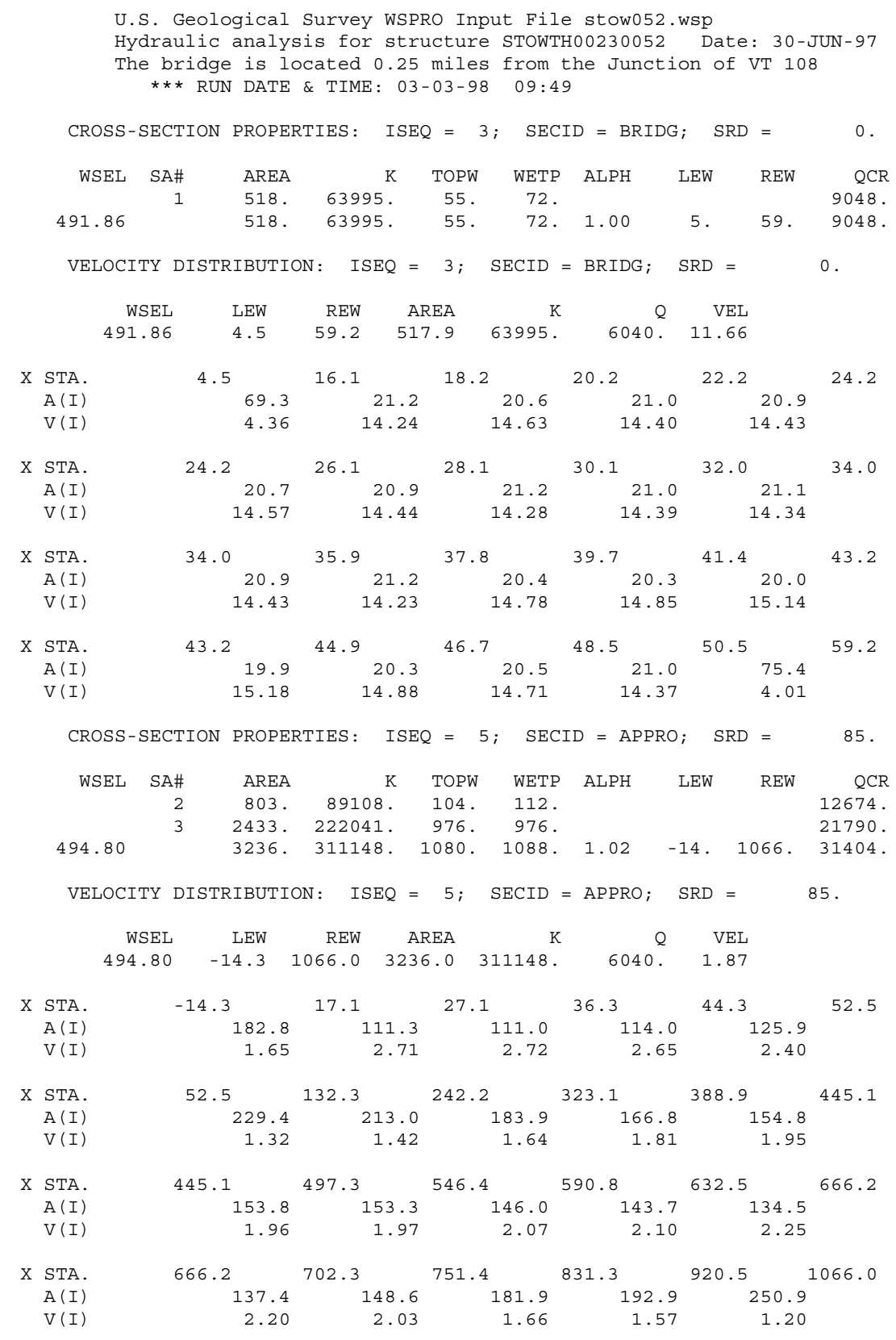


WSPRO OUTPUT FILE (continued)

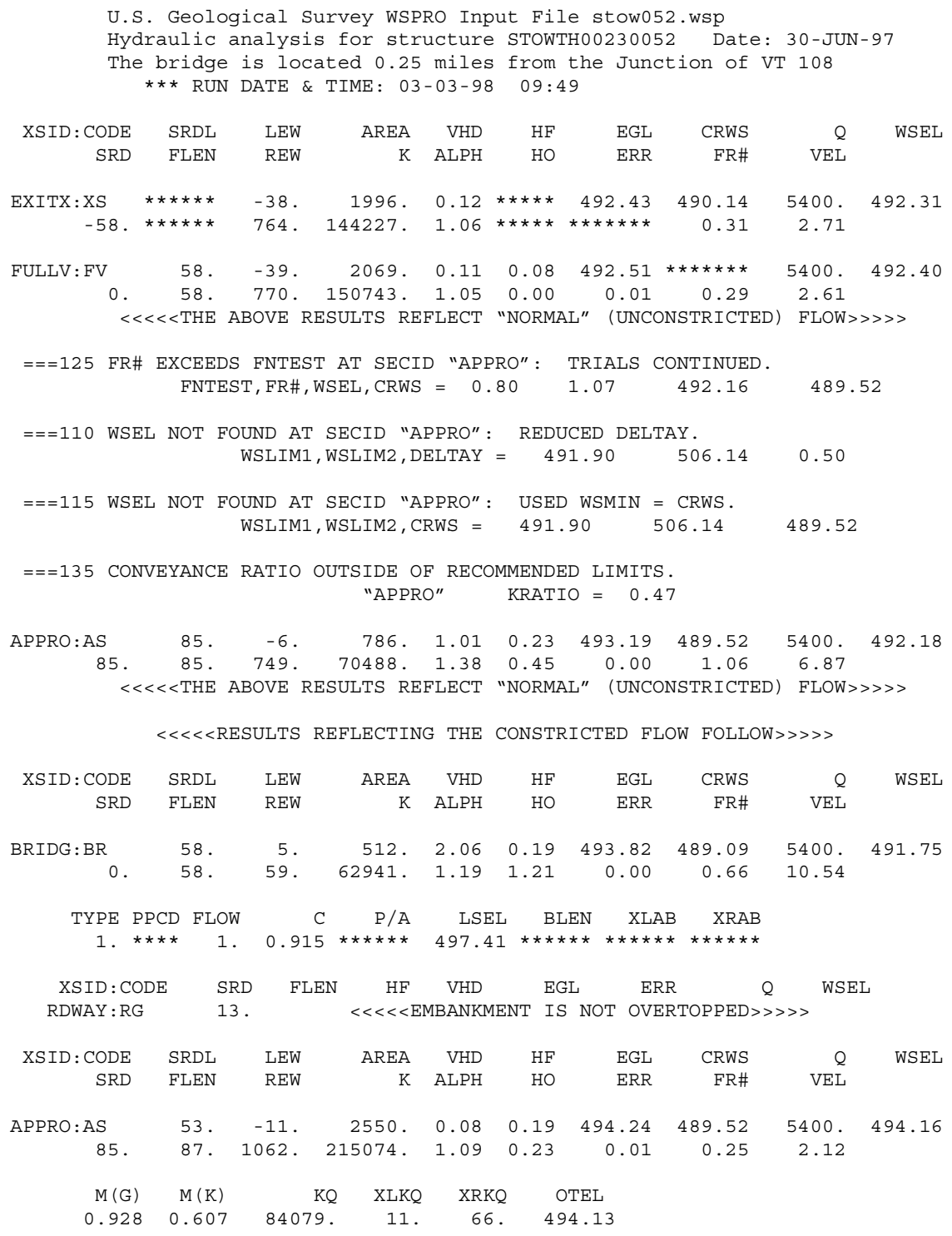

$<<<<$ END OF BRIDGE COMPUTATIONS $>>>>>$

FIRST USER DEFINED TABLE.

\begin{tabular}{|c|c|c|c|c|c|c|c|c|}
\hline XSID : CODE & SRD & LEW & REW & $Q$ & $\mathrm{~K}$ & AREA & VEL & WSEL \\
\hline EXITX:XS & -58. & -38 & 764. & 5400 . & 144227 . & 1996. & 2.71 & 492.31 \\
\hline FULLV : FV & 0 . & -39 & 770. & 5400 . & 150743. & 2069. & 2.61 & 492.40 \\
\hline BRIDG : BR & 0 . & 5 . & 59. & 5400. & 62941. & 512. & 10.54 & 491.75 \\
\hline RDWAY : RG & \multicolumn{3}{|c|}{$13 . * \star \star * \star * \star * \star * * * \star * \star *$} & \multicolumn{3}{|c|}{ 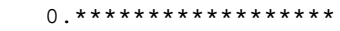 } & \multicolumn{2}{|c|}{$1.00 * * * * * * * *$} \\
\hline APPRO : AS & 85 . & -11 & 1062. & 5400 . & 215074 . & 2550 . & 2.12 & 494.16 \\
\hline XSID : CODE & XLKQ & XRKQ & & & & & & \\
\hline APPRO : AS & 11. & 66. & 84075 & & & & & \\
\hline
\end{tabular}

SECOND USER DEFINED TABLE.

$\begin{array}{lrrrrrrrrr}\text { XSID : CODE } & \text { CRWS } & \text { FR\# } & \text { YMIN } & \text { YMAX } & \text { HF } & \text { HO } & \text { VHD } & \text { EGL } & \text { WSEL } \\ \text { EXITX:XS } & 490.14 & 0.31 & 481.60 & 507.70 * * * * * * * * * * & 0.12 & 492.43 & 492.31 \\ \text { FULLV : FV } & * * * * * * * * & 0.29 & 481.60 & 507.70 & 0.08 & 0.00 & 0.11 & 492.51 & 492.40 \\ \text { BRIDG : BR } & 489.09 & 0.66 & 480.13 & 497.50 & 0.19 & 1.21 & 2.06 & 493.82 & 491.75 \\ \text { RDWAY : RG } & * * * * * * * * * * * * * * * * & 494.74 & 514.17 * * * * * * * * * * * * * * * * * * * * * * * * * * * * * * * \\ \text { APPRO : AS } & 489.52 & 0.25 & 479.17 & 506.14 & 0.19 & 0.23 & 0.08 & 494.24 & 494.16\end{array}$


WSPRO OUTPUT FILE (continued)

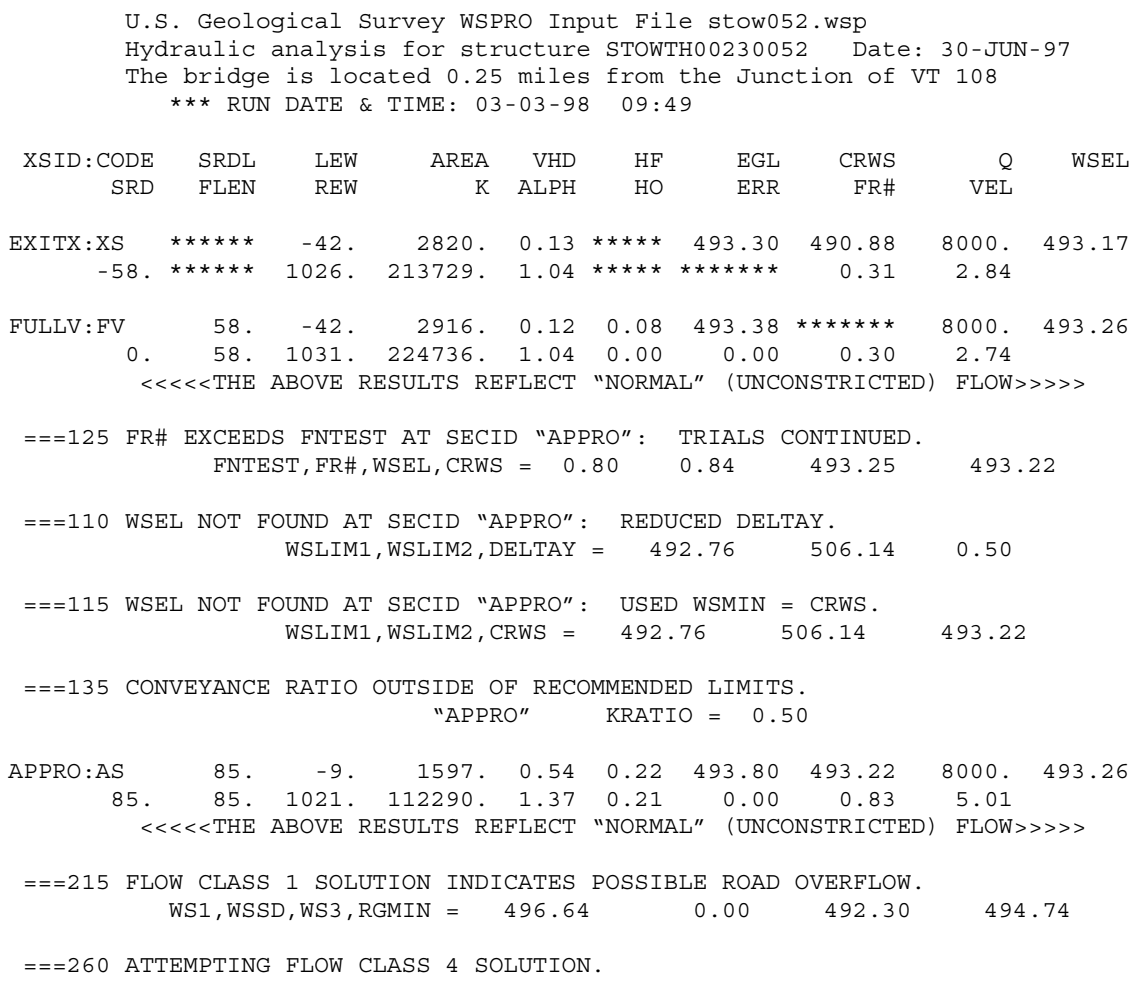

FIRST USER DEFINED TABLE.

\begin{tabular}{|c|c|c|c|c|c|c|c|c|}
\hline XSID: CODE & SRD & LEW & REW & Q & $\mathrm{K}$ & AREA & VEL & WSEL \\
\hline EXITX:XS & -58. & -42 & 1026. & 8000 . & 213729. & 2820 . & 2.84 & 493.17 \\
\hline FULLV : FV & 0 . & -42 & 1031. & 8000 . & 224736 . & 2916. & 2.74 & 493.26 \\
\hline BRIDG : BR & 0 . & 4. & 59. & 6694. & 75487 . & 579. & 11.56 & 492.98 \\
\hline RDWAY : RG & 13. & $* \star \star * *$ & 0 . & 1306. & 0 . & $* * * * * *$ & 1.00 & 495.83 \\
\hline APPRO: AS & 85. & -20 & 1074 . & 8000 . & 535246. & 4534 . & 1.76 & 495.99 \\
\hline XSID: CODE & XLKQ & XRKQ & & & & & & \\
\hline APPRO: AS & 19. & 74. & 91152 & & & & & \\
\hline
\end{tabular}

SECOND USER DEFINED TABLE.

$\begin{array}{lcrrrrrrrr}\text { XSID :CODE } & \text { CRWS } & \text { FR\# } & \text { YMIN } & \text { YMAX } & \text { HF } & \text { HO } & \text { VHD } & \text { EGL } & \text { WSEL } \\ \text { EXITX:XS } & 490.88 & 0.31 & 481.60 & 507.70 * * * * * * * * * * * & 0.13 & 493.30 & 493.17 \\ \text { FULLV:FV } & * * * * * * * & 0.30 & 481.60 & 507.70 & 0.08 & 0.00 & 0.12 & 493.38 & 493.26 \\ \text { BRIDG :BR } & 490.13 & 0.71 & 480.13 & 497.50 & 0.19 & 2.15 & 2.67 & 495.64 & 492.98 \\ \text { RDWAY:RG } & * * * * * * * * * * * * * * & 494.74 & 514.17 & 0.01 * * * * * * & 0.05 & 496.04 & 495.83 \\ \text { APPRO :AS } & 493.22 & 0.15 & 479.17 & 506.14 & 0.15 & 0.25 & 0.05 & 496.04 & 495.99\end{array}$


WSPRO OUTPUT FILE (continued)

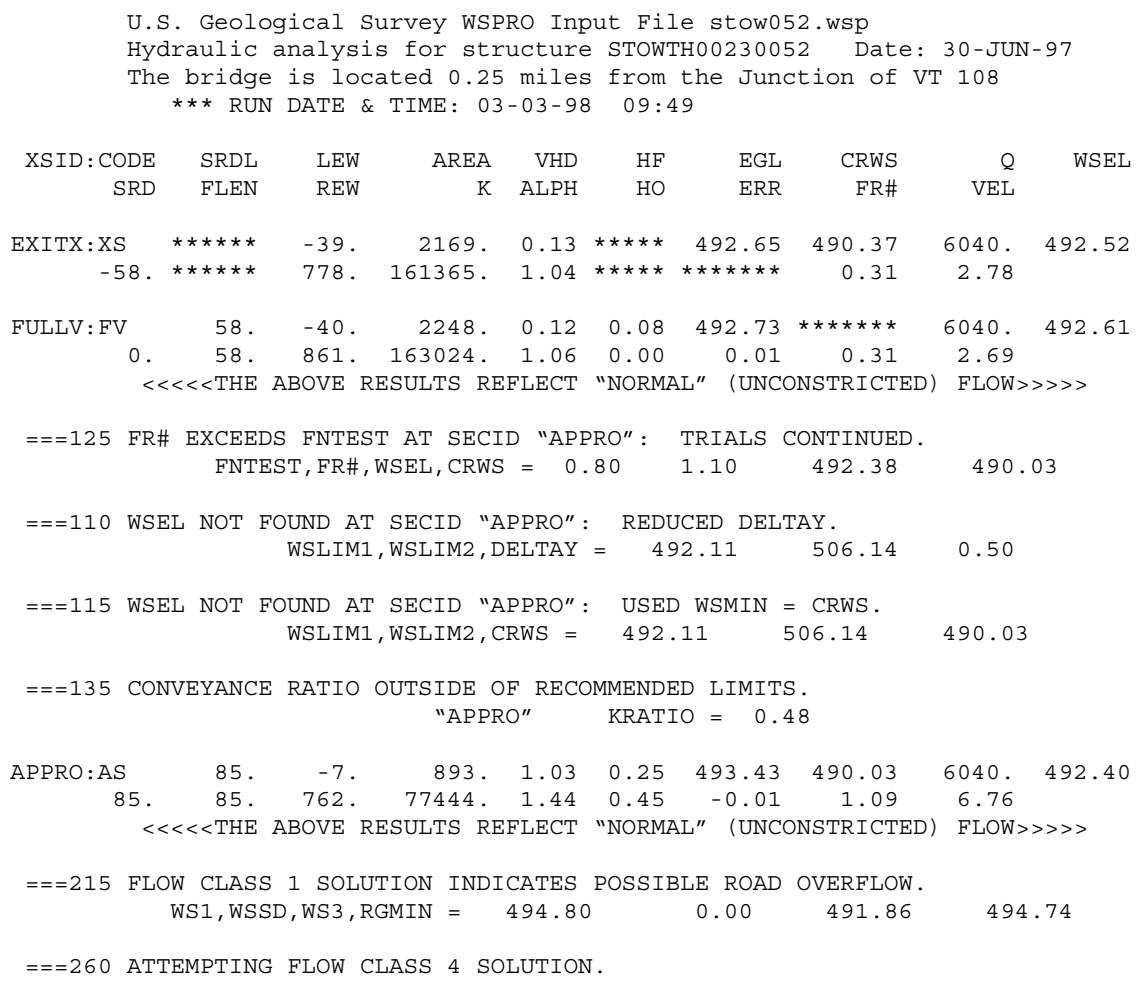




\section{APPENDIX C:}

\section{BED-MATERIAL PARTICLE-SIZE DISTRIBUTION}




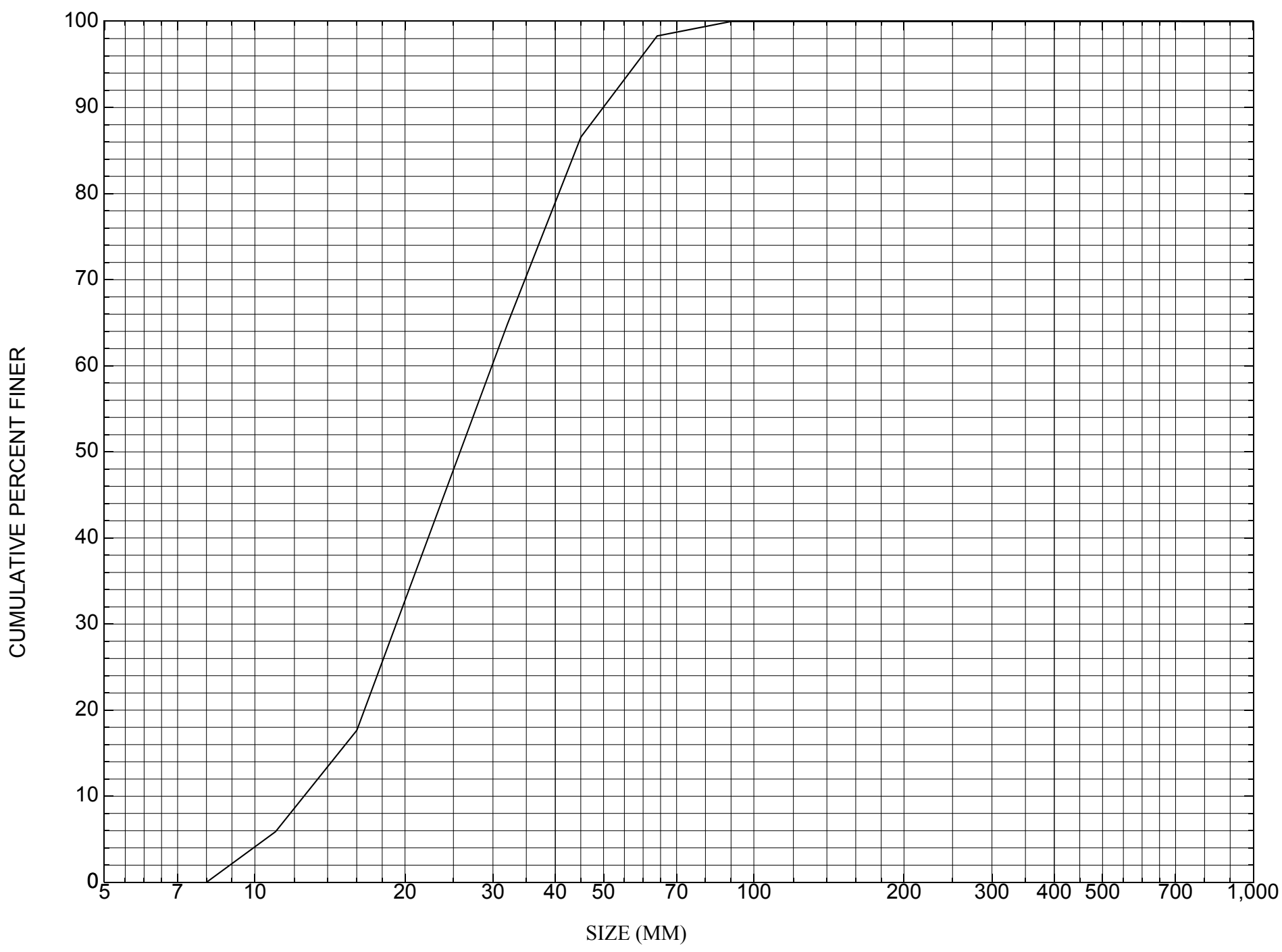

Appendix C. Bed material particle-size distribution for a pebble count in the channel approach of structure STOWTH00230052, in Stowe, Vermont. 


\section{APPENDIX D: \\ HISTORICAL DATA FORM}




\section{Structure Number STOWTH00230052}

\section{General Location Descriptive}

Data collected by (First Initial, Full last name) $\underline{\mathbf{L}}$. Medalie

Date $(M M / D D / Y Y) \_10 / 13 / \underline{95}$

Highway District Number (I - 2; nn) $\mathbf{0 6}$

Town (FIPS place code; I - 4; nnnnn) $\mathbf{7 0 5 2 5}$

Waterway (I - 6) West Branch Little (Waterbury) River

Route Number $\mathbf{C 3 0 2 3}$

Topographic Map Stowe

Latitude (I - 16; nnnn.n) $\mathbf{4 4 2 8 6}$
County (FIPS county code; I - 3; nnn)

Mile marker (I - 11; nnn.nnn) $\mathbf{0 0 0 0 0 0}$

Road Name ( -7$)$ : Weeks Hill Road

Vicinity (I - 9) 0.25 MI TO JCT W VT 108

Hydrologic Unit Code: $\underline{\mathbf{0 2 0 1 0 0 0 3}}$

Longitude (i - 17; nnnnn.n) $\mathbf{7 2 4 1 3}$

\section{Select Federal Inventory Codes}

FHWA Structure Number (I - 8) $\mathbf{1 0 0 8 0 8 0 0 5 2 0 8 0 8}$

Maintenance responsibility $(I-21 ; n n) \_\mathbf{0 3}$

Year built (I - 27; YYYY) 1958

Average daily traffic, ADT (I - 29; nnnnnn) 001500

Year of ADT (I - 30; YY) $\mathbf{9 3}$

Opening skew to Roadway $(I-34 ; n n) \quad \mathbf{0 0}$

Operational status $(I-41 ; X)$ A

Structure type (I - 43; nnn) $\mathbf{3 0 2}$

Approach span structure type $(I-44 ; n n n) \quad \mathbf{0 0 0}$

Number of spans (I - 45; nnn) $\underline{\mathbf{0 0 1}}$

Number of approach spans (I - 46; nnnn) $\mathbf{0 0 0 0}$

Comments:

According to the structural inspection report dated 6/7/95, the deck of the structure consists of concrete with asphalt overlay. The bridge guide rail consists of concrete posts with a 2-cable rail. There are minor cracks and spalls on the RABUT; the LABUT is grouted stone. There are also minor cracks on the wingwalls of the RABUT. Past erosion and undermining problems at both abutments have been corrected. There is a fairly new footing on the LABUT. Past channel scour problems at both abutments have been corrected. There is some stone fill and areas of erosion on the embankments. There is a large gravel bar US of the LABUT. Minor debris is noted.
Maximum span length (I - 48; nnnn) $\underline{0061}$

Structure length (I - 49; nnnnnn) $\underline{\mathbf{0 0 0 0 6 4}}$

Deck Width (I - 52; nn.n) 256

Channel \& Protection $(I-61 ; n) \underline{6}$

Waterway adequacy $(I-71 ; n) \underline{7}$

Underwater Inspection Frequency $(I-92 B ; X Y Y) \_$N

Year Reconstructed (I - 106) $\mathbf{0 0 0 0}$

Clear span (nnn.n ft) $\mathbf{5 3}$

Vertical clearance from streambed (nnn.n ft) $\underline{\mathbf{1 3 . 1}}$

Waterway of full opening $\left(n n n . n \mathrm{ft}^{2}\right) \quad \mathbf{6 9 4}$ 


\section{Bridge Hydrologic Data}

Is there hydrologic data available? $\underline{\mathbf{N}}$ if No, type ctrl-n $h \quad$ VTAOT Drainage area $\left(m i^{2}\right)$ : -

Terrain character:

Stream character \& type: -

Streambed material:

Discharge Data (cfs):

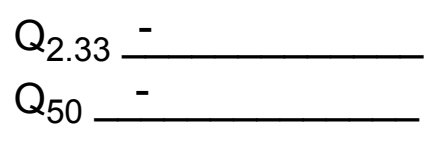

Record flood date $(M M / D D / Y Y):-{ }^{\prime}-\frac{1}{\text { Velocity }}$ at $\mathrm{Q}-$
Estimated Discharge $(c f s):-$

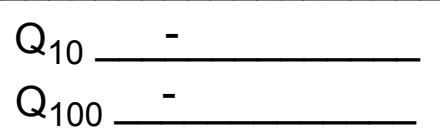

$\mathrm{Q}_{25}$

Water surface elevation $(f t):-$ $(f t / s):$

Ice conditions (Heavy, Moderate, Light) : -

Debris (Heavy, Moderate, Light):

The stage increases to maximum highwater elevation (Rapidly, Not rapidly):

The stream response is (Flashy, Not flashy):

Describe any significant site conditions upstream or downstream that may influence the stream's stage: -

Watershed storage area (in percent):

The watershed storage area is: - (1-mainly at the headwaters; 2- uniformly distributed; 3-immediatly upstream oi the site)

Water Surface Elevation Estimates for Existing Structure:

\begin{tabular}{|l|l|l|l|l|l|}
\hline Peak discharge frequency & $Q_{2.33}$ & $Q_{10}$ & $Q_{25}$ & $Q_{50}$ & $Q_{100}$ \\
Water surface elevation (ft)) & - & - & - & - & - \\
Velocity (ft/sec) & - & - & - & - & - \\
\hline
\end{tabular}

Long term stream bed changes: -

Is the roadway overtopped below the $\mathrm{Q}_{100}$ ? (Yes, No, Unknown): $\mathbf{U}$ Frequency: -

Relief Elevation $(f t)$ :

Discharge over roadway at $\mathrm{Q}_{100}\left(\mathrm{ft}^{3} / \mathrm{sec}\right)$ :

Are there other structures nearby? (Yes, No, Unknown):

Upstream distance (miles):

Town: If No or Unknown, type ctrl-n os

Highway No. : Structure No. : Year Built:

Clear span (ft): Clear Height $(f t)$ : Full Waterway $\left(f^{2}\right)$ : 
Downstream distance (miles): Town: Year Built:

Highway No. : Structure No. : Structure Type:

Clear span (ft): Clear Height $(f t)$ : Full Waterway $\left(f^{2}\right):$

Comments:

\section{USGS Watershed Data}

Watershed Hydrographic Data

Drainage area (DA) 26.7

Watershed storage (ST)

Bridge site elevation 700 $\mathrm{mi}^{2}$ Lake/pond/swamp area $\mathrm{mi}^{2}$

Main channel length 9.95 $\mathrm{ft}$ $\%$ $10 \%$ channel length elevation $\mathrm{mi}$ Headwater elevation 3900 $\mathrm{ft}$

Main channel slope $(S)$
(S) 119.26 $\mathrm{ft} / \mathrm{mi}$

Watershed Precipitation Data

Average site precipitation in Average headwater precipitation in

Maximum 2yr-24hr precipitation event $(124,2)$ in

Average seasonal snowfall (Sn) $\mathrm{ft}$ 


\section{Bridge Plan Data}

Are plans available? $\mathbf{N} \quad$ If no, type ctrl-n pl Date issued for construction (MM / YYYY):

Project Number

Minimum channel bed elevation:

Low superstructure elevation: USLAB DSLAB USRAB DSRAB Benchmark location description:

There is no benchmark information available.

Reference Point (MSL, Arbitrary, Other): Datum (NAD27, NAD83, Other):

Foundation Type: 4

If 1: Footing Thickness

If 2: Pile Type:

If 3: Footing bottom elevation:

Is boring information available? $\mathbf{N}$ Foundation Material Type: 3 (1-Spreadfooting; 2-Pile; 3- Gravity; 4-Unknown) Footing bottom elevation: -

Briefly describe material at foundation bottom elevation or around piles:

There is no foundation material information available.

Comments:

$-$ 


\section{Cross-sectional Data}

Is cross-sectional data available? $\mathbf{N}$ If no, type ctrl-n xs

Source (FEMA, VTAOT, Other)? -

Comments: There is no cross-section information available.

\begin{tabular}{|l|l|l|l|l|l|l|l|l|l|l|l|}
\hline Station & - & - & - & - & - & - & - & - & - & - & - \\
\hline Feature & - & - & - & - & - & - & - & - & - & - & - \\
\hline $\begin{array}{l}\text { Low cord } \\
\text { elevation }\end{array}$ & - & - & - & - & - & - & - & - & - & - & - \\
\hline $\begin{array}{l}\text { Bed } \\
\text { elevation }\end{array}$ & - & - & - & - & - & - & - & - & - & - & - \\
\hline $\begin{array}{l}\text { Low cord to } \\
\text { bed length }\end{array}$ & - & - & - & - & - & - & - & - & - & - & - \\
\hline Station & - & - & - & - & - & - & - & - & - & - & - \\
\hline Feature & - & - & - & - & - & - & - & - & - & - & - \\
\hline $\begin{array}{l}\text { Low cord } \\
\text { elevation }\end{array}$ & - & - & - & - & - & - & - & - & - & - & - \\
\hline $\begin{array}{l}\text { Bed } \\
\text { elevation }\end{array}$ & - & - & - & - & - & - & - & - & - & - & - \\
\hline $\begin{array}{l}\text { Low cord to } \\
\text { bed length }\end{array}$ & - & - & - & - & - & - & - & - & - & - & - \\
\hline
\end{tabular}

Source (FEMA, VTAOT, Other)?

Comments: -

\begin{tabular}{|l|l|l|l|l|l|l|l|l|l|l|l|}
\hline Station & - & - & - & - & - & - & - & - & - & - & - \\
\hline Feature & - & - & - & - & - & - & - & - & - & - & - \\
\hline $\begin{array}{l}\text { Low cord } \\
\text { elevation }\end{array}$ & - & - & - & - & - & - & - & - & - & - & - \\
\hline $\begin{array}{l}\text { Bed } \\
\text { elevation }\end{array}$ & - & - & - & - & - & - & - & - & - & - & - \\
\hline $\begin{array}{l}\text { Low cord to } \\
\text { bed length }\end{array}$ & - & - & - & - & - & - & - & - & - & - & - \\
\hline Station & - & - & - & - & - & - & - & - & - & - & - \\
\hline Feature & - & - & - & - & - & - & - & - & - & - & - \\
\hline $\begin{array}{l}\text { Low cord } \\
\text { elevation }\end{array}$ & - & - & - & - & - & - & - & - & - & - & - \\
\hline $\begin{array}{l}\text { Bed } \\
\text { elevation }\end{array}$ & - & - & - & - & - & - & - & - & - & - & - \\
\hline $\begin{array}{l}\text { Low cord to } \\
\text { bed length }\end{array}$ & - & - & - & - & - & - & - & - & - & - & - \\
\hline
\end{tabular}




\section{APPENDIX E: \\ LEVEL I DATA FORM}


U. S. Geological Survey

Bridge Field Data Collection and Processing Form

Qa/Qc Check by: $\underline{\mathbf{R B}}$ Date: $10 / 23 / 96$

\section{Structure Number STOWTH00230052}

Computerized by: $\underline{\mathbf{R B}}$ Date: $10 / 24 / 96$

Reviewd by: LKS Date: $\underline{07 / 08 / 97}$

\section{A. General Location Descriptive}

1. Data collected by (First Initial, Full last name) L. MEDALIE

Date $(M M / D D / Y Y) \mathbf{0 7} / \underline{10 / 1996}$

2. Highway District Number 06

Mile marker $\mathbf{0 0 0 0}$

County Lamoille (015)

Town Stowe (70525)

Waterway (I - 6) West Branch Little (Waterbury) River Road Name Weeks Hill Road

Route Number $\mathbf{C 3 0 2 3}$

Hydrologic Unit Code: $\mathbf{0 2 0 1 0 0 0 3}$

3. Descriptive comments:

The bridge is located 1/4 of a mile from the junction with VT 108. The bridge has an asphalt deck.

\section{B. Bridge Deck Observations}
4. Surface cover... LBUS 5
RBUS 4
LBDS 5
RBDS 4
Overall 4

(2b us, ds,lb,rb: 1- Urban; 2- Suburban; 3- Row crops; 4- Pasture; 5- Shrub- and brushland; 6- Forest; 7- Wetland)
5. Ambient water surface... US 1
UB 1
DS 1
(1- pool; 2- riffle)

6. Bridge structure type 1 (1- single span; 2- multiple span; 3- single arch; 4- multiple arch; 5-cylindrical culvert; 6- box culvert; or 7- other)
7. Bridge length 64
(feet)
Span length 61
(feet)
Bridge width 25.6 (feet)

\section{Road approach to bridge:}
8. LB 2 RB 1
( 0 even, 1- lower, 2- higher)
9. $\mathrm{LB}$
RB 1
(1- Paved, 2- Not paved)

10. Embankment slope (run / rise in feet / foot)

US left

US right

\begin{tabular}{|c|c|c|c|}
\hline \multicolumn{2}{|c|}{ Protection } & \multirow{2}{*}{ 13.Erosion } & 14.Severity \\
\hline 11.Type & 12.Cond. & - & $\underline{\mathbf{2}}$ \\
\hline $\mathbf{0}$ & - & $\mathbf{0}$ & - \\
\hline $\mathbf{0}$ & - & $\underline{\mathbf{0}}$ & $\mathbf{1}$ \\
\hline $\mathbf{0}$ & - & $\underline{\mathbf{2}}$ & $\mathbf{1}$ \\
\hline $\mathbf{0}$ & - & $\underline{\mathbf{2}}$ & $\mathbf{1}$ \\
\hline
\end{tabular}

Bank protection types: 0- none; 1- < 12 inches;

2- $<36$ inches; $3-<48$ inches;

4- < 60 inches; 5- wall / artificial levee

Bank protection conditions: 1- good; 2- slumped;

3- eroded; 4- failed

Erosion: 0 - none; 1- channel erosion; 2 -

road wash; 3- both; 4- other

Erosion Severity: 0 - none; 1- slight; 2- moderate; 3- severe

\section{Channel approach to bridge (BF):}

15. Angle of approach: $\mathbf{5}$

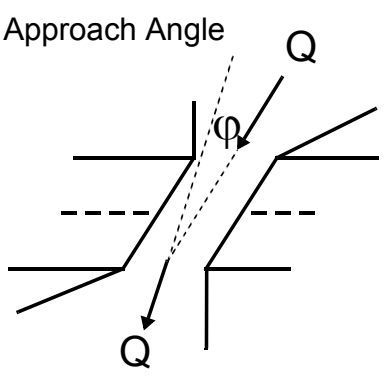

17. Channel impact zone 1 :

Where? RB (LB, RB)

Range? 126 feet $\underline{\text { US }}$

Channel impact zone 2:

Where? RB (LB, RB)

Range? $\underline{\mathbf{0}}$ feet $\underline{\mathbf{U S}}$

Impact Severity: 0- none to very slight; 1- Slight; 2- Moderate; 3- Severe
16. Bridge skew: 15 Bridge Skew Angle

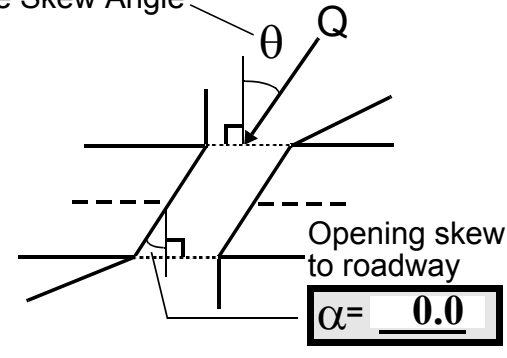

\section{Exist? $\underline{\mathbf{Y}}(\mathrm{Y}$ or $N)$}

Severity 2

(US, UB, DS) to $\underline{35}$ feet $\underline{\mathbf{U S}}$

Exist? $\mathbf{Y}(Y$ or $N)$

Severity $\underline{1}$

, UB, DS) to 20 feet $\underline{\mathbf{D S}}$ 
18. Bridge Type: $\underline{\mathbf{1 a} / \mathbf{1 b}}$

1a- Vertical abutments with wingwalls

1 b- Vertical abutments without wingwalls

2- Vertical abutments and wingwalls, sloping embankment Wingwalls parallel to abut. face

3- Spill through abutments

4- Sloping embankment, vertical wingwalls and abutments

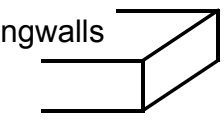

Wingwall angle less than $90^{\circ}$.
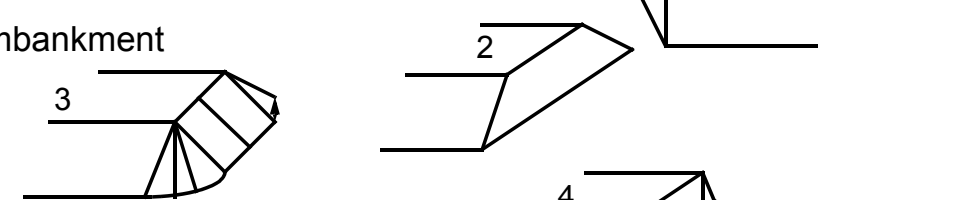

19. Bridge Deck Comments (surface cover variations, measured bridge and span lengths, bridge type variations, approach overflow width, etc.)

4. The left bank US has shrubs close to the bridge then lawn after $100 \mathrm{ft}$. Moving bankward, there is a gravel road and more shrubs and pasture beyond the road. The right banks US and DS are pasture that has been recently cut. The vegetation on the left bank DS is shrubs for $100 \mathrm{ft}$ and then row crops.

7. Bridge measurement values are from the VT AOT files. The measured bridge length is $64 \mathrm{ft}$, bridge span is $58 \mathrm{ft}$, and the deck width is $\mathbf{2 5 . 5} \mathbf{f t}$.

11. The road approach erosion on the right and left banks DS and the left bank US is very slight consisting of minor erosion around the end of the wingwalls.

18. The left abutment is vertical without wingwalls and the right abutment is vertical with wingwalls.

\section{Upstream Channel Assessment}

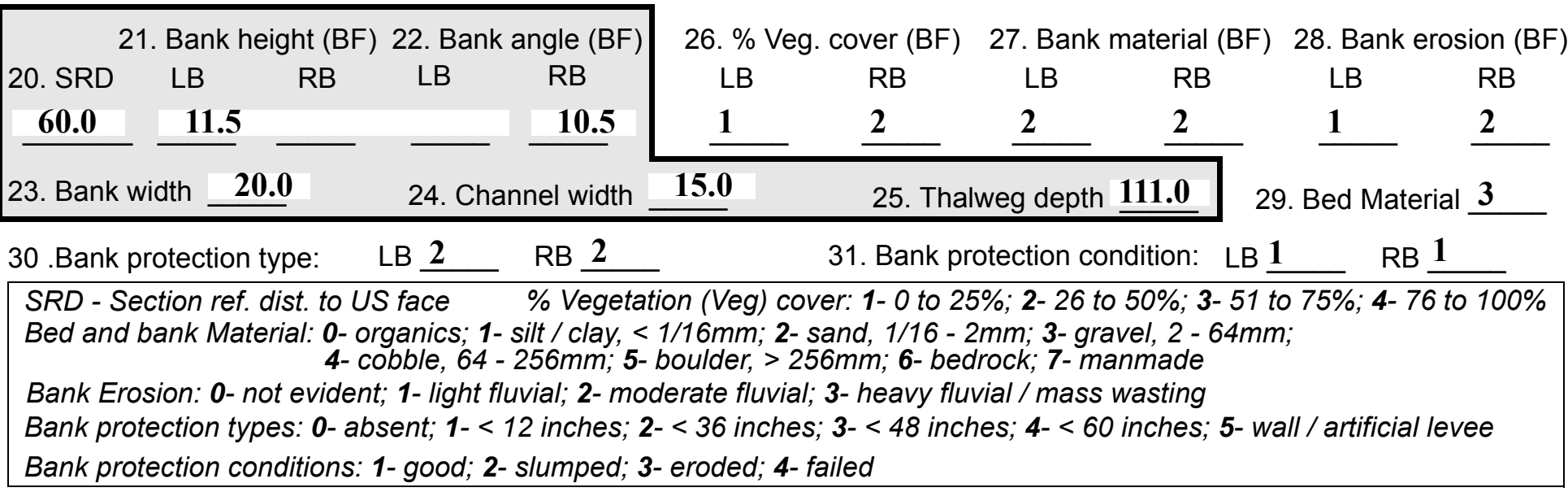

32. Comments (bank material variation, minor inflows, protection extent, etc.):

26. From the bridge to $60 \mathrm{ft}$ US the left bank vegetation cover is between $0 \%$ and $25 \%$, the vegetation cover then increases to between $51 \%$ to $75 \%$, consisting mainly of shrubs and brush.

30. On the right bank the protection extends from the bridge to $93 \mathrm{ft}$. From $73 \mathrm{ft}$ US to $79 \mathrm{ft}$ US there are also 3 large type-3 boulders on the right bank. On the left bank, the protection is from the bridge to $59 \mathrm{ft}$ US. 31. The left bank protection is well above the annual flood line, while the right bank protection extends to the bottom of the channel. The average US thalweg depth is $1.25 \mathrm{ft}$. 
36. Point bar extent: 20 feet US (US, UB) to 155 feet $\underline{\text { US }}$ (US, UB, DS) positioned $\underline{\mathbf{0}}$ $\%$ LB to 60 $\% \mathrm{RB}$

37. Material: $\mathbf{3 4}$

38. Point or side bar comments (Circle Point or Side; Note additional bars, material variation, status, etc.):

The point bar is mostly gravel with some cobbles and sparse vegetation at the upstream end.

39. Is a cut-bank present? $\mathbf{Y}$ ( $Y$ or if $N$ type ctrl-n $c b)$ 40. Where? $\mathbf{R B}$ ( $L B$ or RB)

41. Mid-bank distance: $\mathbf{1 2 0}$

42. Cut bank extent: 185

US, UB) to $\underline{\mathbf{2 0}}$ feet $\underline{\mathbf{U S}}$ (US, UB, DS)

43. Bank damage: 2

(1- eroded and/or creep; 2- slip failure; 3- block failure)

44. Cut bank comments (eg. additional cut banks, protection condition, etc.):

\section{Is channel scour present? $\mathbf{Y}$ (Y or if $N$ type ctrl-n cs) $\quad$ 46. Mid-scour distance: 69 \\ 47. Scour dimensions: Length $\underline{\mathbf{1 1 0}}$ Width $\underline{\mathbf{8}}$ Depth : $\underline{\mathbf{3}} \quad$ Position $\underline{\mathbf{7 5}} \%$ LB to $\underline{\mathbf{9 0}} \% \mathrm{RB}$ \\ 48. Scour comments (eg. additional scour areas, local scouring process, etc.):}

Channel scour has occurred where the flow bends at the impact zone. The width and depth were measured at the mid-scour distance from the bridge. The depth at the upstream and downstream ends of the scour is $1 \mathrm{ft}$.

\section{Are there major confluences? $\mathbf{N}$}

51. Confluence 1: Distance -

Confluence 2: Distance -

54. Confluence comments (eg. confluence name):

There are no major confluences upstream at this site.
( $Y$ or if $N$ type ctrl-n $m c)$

52. Enters on ( $L B$ or $R B$ )

Enters on (LB or $R B)$
50. How many? -

53. Type(1-perennial; 2- ephemeral)

Type (1-perennial; 2-ephemeral)

\section{Under Bridge Channel Assessment}

55. Channel restraint (BF)? LB 2

\begin{tabular}{|ccccc}
\hline \multicolumn{2}{|c}{56. Height (BF) } & \multicolumn{3}{c}{57 Angle (BF) } \\
LB & RB & LB & RB \\
$\mathbf{4 6 . 0}$ & & & $\mathbf{1 . 0}$ & \\
\hline
\end{tabular}

58. Bank width (BF) (1- natural bank; 2- abutment; 3- artificial levee)

Bed and bank Material: 0- organics; 1- silt / clay, < 1/16mm; 2- sand, 1/16 - 2mm; 3- gravel, 2 - 64mm; 4- cobble, 64 - 256mm; 5- boulder, > 256mm; 6- bedrock; 7- manmade

61. Material (BF) 62. Erosion (BF)

LB RB LB RB

$\underline{2} \quad \underline{7} \quad \underline{-}$

59. Channel width -

60. Thalweg depth $\mathbf{9 0 . 0}$

63. Bed Material -

Bank Erosion: 0- not evident; 1- light fluvial; 2- moderate fluvial; 3- heavy fluvial / mass wasting

64. Comments (bank material variation, minor inflows, protection extent, etc.):

34 
65. Debris and Ice Is there debris accumulation?

67. Debris Potential $\underline{2}$ ( 1- Low; 2- Moderate; 3- High)

69. Is there evidence of ice build-up? 1 (Y or $N)$

70. Debris and Ice Comments:

1

The debris accumulation is minimal.
(Yor $N)$ 66. Where? $\mathbf{Y}$

(1- Upstream; 2- At bridge; 3- Both)

68. Capture Efficiency 1

(1-Low; 2- Moderate; 3- High)

Ice Blockage Potential Y

\begin{tabular}{|l|c|c|c|c|c|c|c|c|}
\hline Abutments & $\begin{array}{c}\text { 71. Attack } \\
\angle \text { (BF) }\end{array}$ & $\begin{array}{c}\text { 72. Slope } \angle \\
\text { (Qmax) }\end{array}$ & $\begin{array}{c}\text { 73. Toe } \\
\text { loc. (BF) }\end{array}$ & $\begin{array}{c}\text { 74. Scour } \\
\text { Condition }\end{array}$ & $\begin{array}{c}\text { 75. Scour } \\
\text { depth }\end{array}$ & $\begin{array}{c}\text { 76. Exposure } \\
\text { depth }\end{array}$ & 77. Material & 78. Length \\
\hline LABUT & & $\mathbf{0}$ & $\mathbf{8 5}$ & $\mathbf{2}$ & $\mathbf{2}$ & $\mathbf{0}$ & $\mathbf{1}$ & $\mathbf{9 0 . 0}$ \\
\hline RABUT & $\mathbf{2}$ & $\mathbf{0}$ & $\mathbf{9 0}$ & & & $\mathbf{2}$ & $\mathbf{3}$ & $\mathbf{5 9 . 5}$ \\
\hline
\end{tabular}

Pushed: $L B$ or RB

Toe Location (Loc.): 0- even, 1- set back, 2- protrudes

Scour cond.: 0- not evident; 1- evident (comment); 2- footing exposed; 3-undermined footing; 4- piling exposed; 5- settled; 6- failed

Materials: 1- Concrete; 2- Stone masonry or drywall; 3- steel or metal; 4- wood

79. Abutment comments (eg. undermined penetration, unusual scour processes, debris, etc.):

2

4

1

71. At low flow the attack is on the left abutment, but the main channel runs along the right abutment.

74. On the right abutment, the concrete footing is exposed $2 \mathrm{ft}$ at the DS end and $4 \mathrm{ft}$ at the US end. There is a fence of vertical $2 \mathrm{in}$. $x 4 \mathrm{in}$. boards jointed together in front of the footing. At the DS end, $2 \mathrm{ft}$ of the fence is exposed and $3 \mathrm{ft}$ is exposed on the US end.

The wood fence in undermined up to 6 in. in areas at the US end and is leaning into the stream at a 25 degree angle. At the DS end, the fence is not undermined and is vertical. The concrete behind the wooden fence at the US end is undermined up to 6 in.

75. The US scour hole extends under the bridge and is $2 \mathrm{ft}$ deep $6 \mathrm{ft}$ into the channel from the footing fence.

77. The left abutment is a $6 \mathrm{ft}$ high wall of "laid-up" stone wall with a concrete footing and a $2 \mathrm{ft}$ concrete bridge seat set back $5 \mathrm{ft}$ from the face of the stone abutment. Below the footing and sloping at a 45 degree angle is stone fill protection, which acts similar to

80. Wingwalls: Exist? Material? Scour Scour Exposure $\begin{aligned} & 81 \text { Angle? Length? } \\ & \text { Condition? depth? depth? }\end{aligned}$

USLWW: a spill throu

USRWW: type \begin{tabular}{l|l} 
gh & $\mathbf{5 9 . 5}$
\end{tabular}

DSLWW: The

DSRWW: left abuttop of

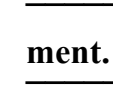

the abut-

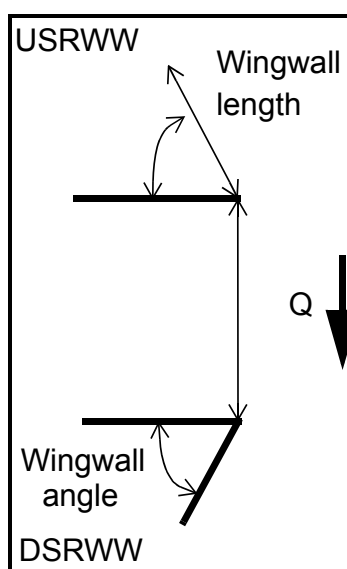

USLWW

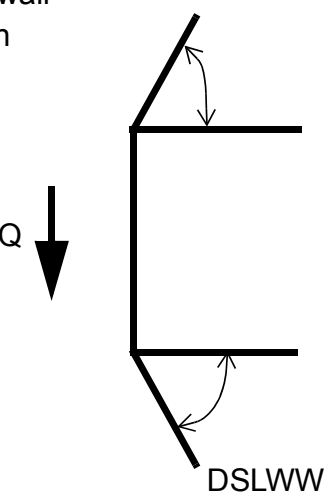

1- Concrete; 2- Stone masonry or drywall; 3- steel or metal; 4- wood

\section{.}


83. Wingwall and protection comments (eg. undermined penetration, unusual scour processes, etc.):

-
-
Y
1
0
-
-
-
-

\section{Piers:}

84. Are there piers? $\mathbf{3}$ (Y or if $N$ type ctrl-n pr)

\begin{tabular}{|l|l|l|l|l|l|l|l|}
\hline \multirow{2}{*}{$\begin{array}{l}85 . \\
\text { Pier no. }\end{array}$} & \multicolumn{3}{|c|}{ width (w) feet } & \multicolumn{3}{c|}{ elevation (e) feet } \\
\cline { 2 - 8 } & w1 & w2 & w3 & e@w1 & e@w2 & e@w3 \\
\hline Pier 1 & - & & & - & $\mathbf{5 0 . 0}$ & $\mathbf{1 6 . 0}$ \\
\hline Pier 2 & - & & & - & $\mathbf{5 5 . 0}$ & $\mathbf{1 6 . 5}$ \\
\hline Pier 3 & - & - & - & - & - & - \\
\hline Pier 4 & - & - & - & - & - & - \\
\hline
\end{tabular}

\begin{tabular}{|l|l|l|l|l|}
\hline Level 1 Pier Descr. & \multicolumn{1}{|c|}{1} & \multicolumn{1}{|c|}{2} & \multicolumn{1}{|c|}{3} & 4 \\
\hline 86. Location (BF) & 1 & - & pro- & \\
\hline 87. Type & 1 & - & tec- & \\
\hline 88. Material & 2 & - & tion & \\
\hline 89. Shape & 1 & - & is set & \\
\hline 90. Inclined? & 1 & - & in & \\
\hline 91. Attack $\angle$ (BF) & 2 & 2 & the & \\
\hline 92. Pushed & 1 & 1 & chan & N \\
\hline 93. Length (feet) & - & - & - & - \\
\hline 94. \# of piles & $\mathbf{2}$ & $\mathbf{2}$ & nel. & - \\
\hline 95. Cross-members & - & The & & - \\
\hline 96. Scour Condition & - & right & & - \\
\hline 97. Scour depth & - & abut & & - \\
\hline 98. Exposure depth & - & ment & & - \\
\hline
\end{tabular}

LFP, LTB, LB, MCL, MCM, MCR, RB, RTB, RFP

1- Solid pier, 2-column, 3- bent

1-Wood; 2- concrete; 3- metal; 4- stone

1- Round; 2- Square; 3- Pointed

Y-yes; $N$ - no

$L B$ or $R B$

0- none; 1- laterals; 2- diagonals; 3- both

0- not evident; 1- evident (comment);

2- footing exposed; 3- piling exposed;

4- undermined footing; 5- settled; 6-failed 
99. Pier comments (eg. undermined penetration, protection and protection extent, unusual scour processes, etc.):

-
-
-
-
-
-
-
-
-

100.

\section{E. Downstream Channel Assessment}

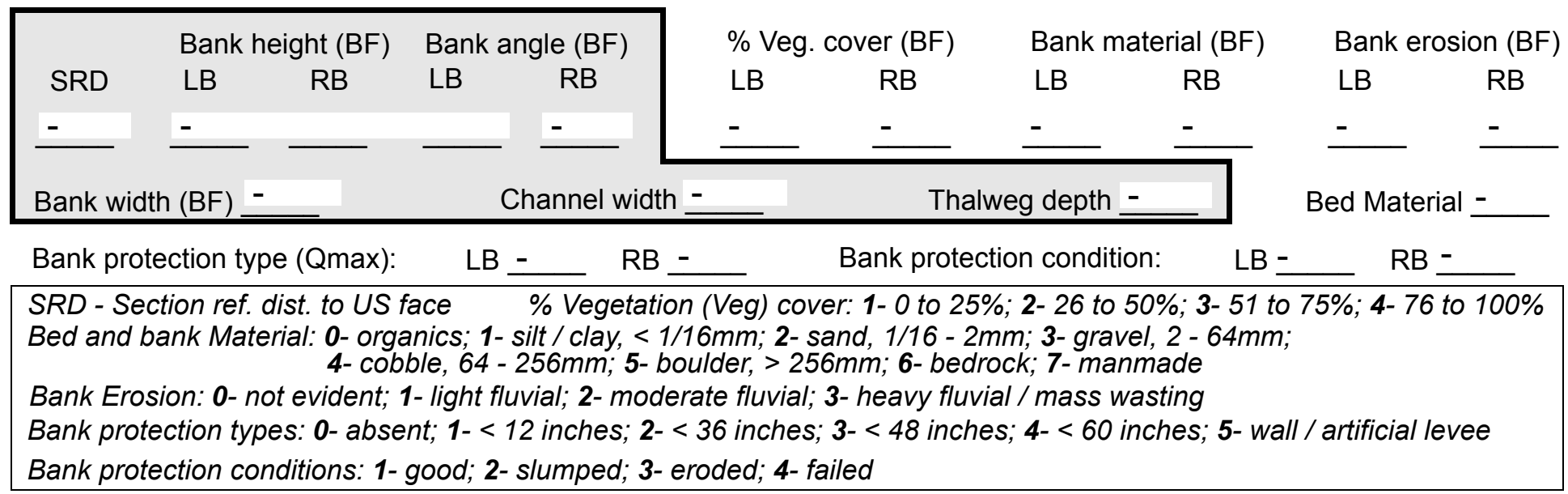

Comments (eg. bank material variation, minor inflows, protection extent, etc.):

$-$

$-$

$-$

$-$

$-$

$-$

$-$

$-$

$-$

$-$

$-$

$-$

$-$

$-$

$-$

101. Is a drop structure present? _ ( $Y$ or $N$, if $N$ type ctrl-n ds) 102. Distance: ___ feet 103. Drop: -_ feet 104. Structure material: ___ (1- steel sheet pile; 2- wood pile; 3- concrete; 4- other) 105. Drop structure comments (eg. downstream scour depth):

$-$

$-$

$-$

$-$

There are no piers. 
106. Point/Side bar present? (Y or N. if $N$ type ctrl-n pb)Mid-bar distance:

Mid-bar width:

Point bar extent: feet

(US, UB, DS) to feet (US, UB, DS) positioned \%LB to $\% R B$

Material: 1

Point or side bar comments (Circle Point or Side; note additional bars, material variation, status, etc.):

1

2

2

1

Is a cut-bank present? 1 (Y or if $N$ type ctrl-n $c b)$ Where? $\underline{3}$ (LB or RB) Mid-bank distance: $\underline{\mathbf{2}}$ Cut bank extent: $\underline{\mathbf{2}}$ feet $\underline{\mathbf{1}}$ (US, UB, DS) to $\underline{\mathbf{1}}$ feet $\underline{\mathbf{T h}}$ (US, UB, DS)

Bank damage: e (1- eroded and/or creep; 2- slip failure; 3- block failure)

Cut bank comments (eg. additional cut banks, protection condition, etc.):

vegetation cover on the left bank is weeds and shrubs to $64 \mathrm{ft}$ DS. Beyond $64 \mathrm{ft}$ DS, there is one tree and more brush. On the right bank the vegetation cover is large shrubs, but there are no trees until $95 \mathrm{ft}$ DS. The downstream bank protection extends to $32 \mathrm{ft}$ DS on the right bank and $53 \mathrm{ft}$ DS on the left bank. The left bank protection is type-2 stone fill located on the lower part of the embankment and type-1 stone fill located higher on Is channel scour present? the ( $Y$ or if $N$ type ctrl-n cs) Mid-scour distance: emba Scour dimensions: Length $\underline{\mathbf{n k m}}$ Width ent. Depth: The Positioned $\underline{\text { re }} \%$ LB to is a $\%$ RB Scour comments (eg. additional scour areas, local scouring process, etc.):

short stretch of erosion on the left bank with block failure at $115 \mathrm{ft}$ DS where the bank is vertical.

Are there major confluences? ( $Y$ or if $N$ type ctrl-n $m c)$

How many?

Confluence 1: Distance Enters on (LB or $R B)$

Type (1- perennial; 2- ephemeral)

Confluence 2: Distance Enters on $\mathbf{N}$ (LB or $R B)$

Type (1- perennial; 2- ephemeral)

Confluence comments (eg. confluence name):

There is no drop structure at this site.

\section{F. Geomorphic Channel Assessment}

107. Stage of reach evolution
1- Constructed

2- Stable

3- Aggraded

4- Degraded

5- Laterally unstable

6- Vertically and laterally unstable 
108. Evolution comments (Channel evolution not considering bridge effects; See HEC-20, Figure 1 for geomorphic descriptors):

$\mathbf{N}$

$-$

$-$

$-$

$-$

$-$

$-$

-

$-$ 


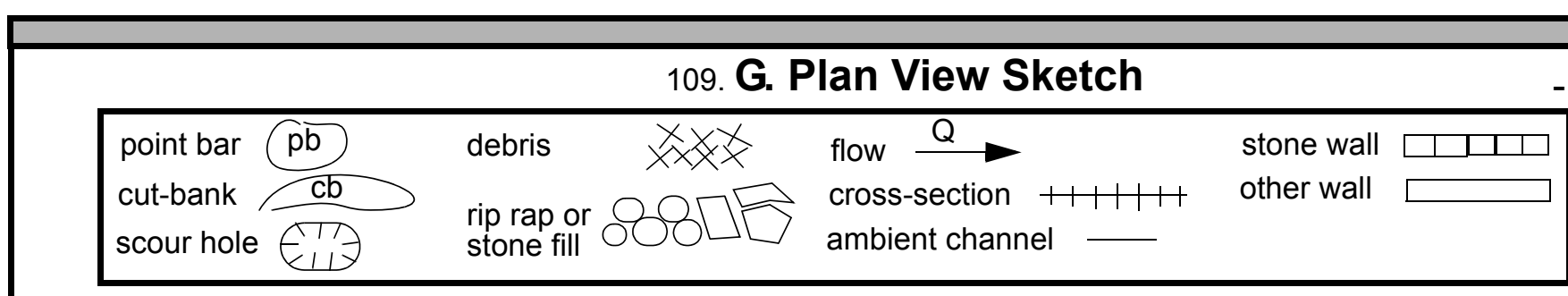

cut-bank $\mathrm{cb}$

scour hole rip rap or
stone fill stone fill cross-section $+1+1+1$ ambient channe other wall 
APPENDIX F:

SCOUR COMPUTATIONS 
SCOUR COMPUTATIONS

\begin{tabular}{|c|c|c|c|}
\hline $\begin{array}{ll}\text { Structure Number: } & \text { STOWTH00230052 } \\
\text { Road Number: } & \text { TH } 23\end{array}$ & & $\begin{array}{l}\text { Town: } \\
\text { County: }\end{array}$ & $\begin{array}{l}\text { STOWE } \\
\text { LAMOILLE }\end{array}$ \\
\hline W. BRANCH LITTLE & (WATERBURY & Y) RIVER & \\
\hline Initials LKS & Checked: & MAI & \\
\hline nalysis of contraction scour, live & -bed or $\mathrm{cl}$ & lear wa & \\
\hline $\begin{array}{l}\text { Critical Velocity of Bed Material } \\
\text { VC=11.21*y } 1^{\wedge} 0.1667 * D 50^{\wedge} 0.33 \text { with Ss } \\
\text { (Richardson and others, } 1995, \text { p. } 28\end{array}$ & $\begin{array}{l}\text { converted } \\
=2.65 \\
\text { eq. } 16)\end{array}$ & to Eng & sh units) \\
\hline Approach Section & & & \\
\hline Characteristic & $100 \mathrm{yr}$ & $500 \mathrm{yr}$ & other $Q$ \\
\hline Total discharge, cfs & 5400 & 8000 & 6040 \\
\hline Main Channel Area, ft2 & 738 & 930 & 803 \\
\hline Left overbank area, ft2 & 0 & 0 & 0 \\
\hline Right overbank area, ft2 & 1809 & 3599 & 2433 \\
\hline Top width main channel, ft & 101 & 109 & 104 \\
\hline Top width L overbank, ft & 0 & 0 & 0 \\
\hline Top width $\mathrm{R}$ overbank, ft & 972 & 984 & 976 \\
\hline D50 of channel, ft & 0.0848 & 0.0848 & 0.0848 \\
\hline D50 left overbank, ft & -- & -- & -- \\
\hline D50 right overbank, ft & -- & -- & -- \\
\hline y1, average depth, MC, ft & 7.3 & 8.5 & 7.7 \\
\hline Y1, average depth, LOB, ft & ERR & ERR & ERR \\
\hline $\mathrm{y}^{1}$, average depth, ROB, ft & 1.9 & 3.7 & 2.5 \\
\hline Total conveyance, approach & 214656 & 534451 & 311148 \\
\hline Conveyance, main channel & 78723 & 110169 & 89108 \\
\hline Conveyance, LOB & 0 & 0 & 0 \\
\hline Conveyance, ROB & 135933 & 424282 & 222041 \\
\hline Percent discrepancy, conveyance & 0.0000 & 0.0000 & -0.0003 \\
\hline Qm, discharge, MC, cfs & 1980.4 & 1649.1 & 1729.8 \\
\hline Q1, discharge, LOB, Cfs & 0.0 & 0.0 & 0.0 \\
\hline Qr, discharge, ROB, Cfs & 3419.6 & 6350.9 & 4310.3 \\
\hline $\mathrm{Vm}$, mean velocity $\mathrm{MC}$, ft/s & 2.7 & 1.8 & 2.2 \\
\hline Vl, mean velocity, LOB, ft/s & ERR & ERR & ERR \\
\hline Vr, mean velocity, ROB, ft/s & 1.9 & 1.8 & 1.8 \\
\hline Vc-m, crit. velocity, $\mathrm{MC}, \mathrm{ft} / \mathrm{s}$ & 6.9 & 7.0 & 6.9 \\
\hline Vc-l, crit. velocity, LOB, ft/s & ERR & ERR & ERR \\
\hline Vc-r, crit. velocity, ROB, ft/s & $\mathrm{ERR}$ & $\mathrm{ERR}$ & $\mathrm{ERR}$ \\
\hline Result: & & & \\
\hline Live-bed(1) or Clear-Water(0) Contr & faction $\mathrm{S}$ & our? & \\
\hline Main Channel & 0 & 0 & 0 \\
\hline Left Overbank & $\mathrm{N} / \mathrm{A}$ & $\mathrm{N} / \mathrm{A}$ & $\mathrm{N} / \mathrm{A}$ \\
\hline Right Overbank & $\mathrm{N} / \mathrm{A}$ & $\mathrm{N} / \mathrm{A}$ & $\mathrm{N} / \mathrm{A}$ \\
\hline
\end{tabular}


Clear Water Contraction Scour in MAIN CHANNEL

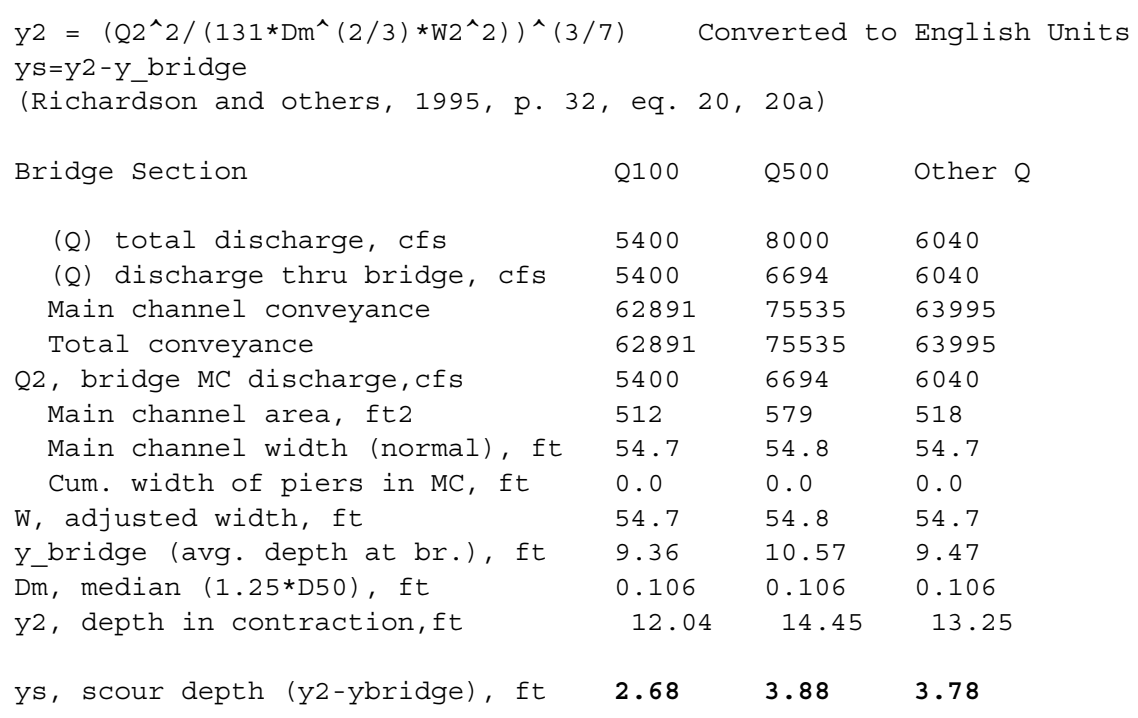

\section{Armoring}

$\mathrm{DC}=\left[\left(1.94 * \mathrm{~V}^{\wedge} 2\right) /(5.75 * \log (12.27 * \mathrm{y} / \mathrm{D} 90))^{\wedge} 2\right] /[0.03 *(165-62.4)]$

Depth to Armoring $=3 *(1 / \mathrm{PC}-1)$

(Federal Highway Administration, 1993)

$\begin{array}{llll}\text { Downstream bridge face property } & 100-y r & 500-y r & \text { Other Q } \\ \text { Q, discharge thru bridge MC, cfs } & 5400 & 6694 & 6040 \\ \text { Main channel area (DS), ft2 } & 512 & 579 & 518 \\ \text { Main channel width (normal), ft } & 54.7 & 54.8 & 54.7 \\ \text { Cum. width of piers, ft } & 0.0 & 0.0 & 0.0 \\ \text { Adj. main channel width, ft } & 54.7 & 54.8 & 54.7 \\ \text { D90, ft } & 0.1637 & 0.1637 & 0.1637 \\ \text { D95, ft } & 0.1901 & 0.1901 & 0.1901 \\ \text { DC, critical grain size, ft } & 0.2618 & 0.3033 & 0.3188 \\ \text { PC, Decimal percent coarser than DC } 0.006 & 0.000 & 0.000\end{array}$

Depth to armoring, ft $\quad$ N/A N/A N/A 


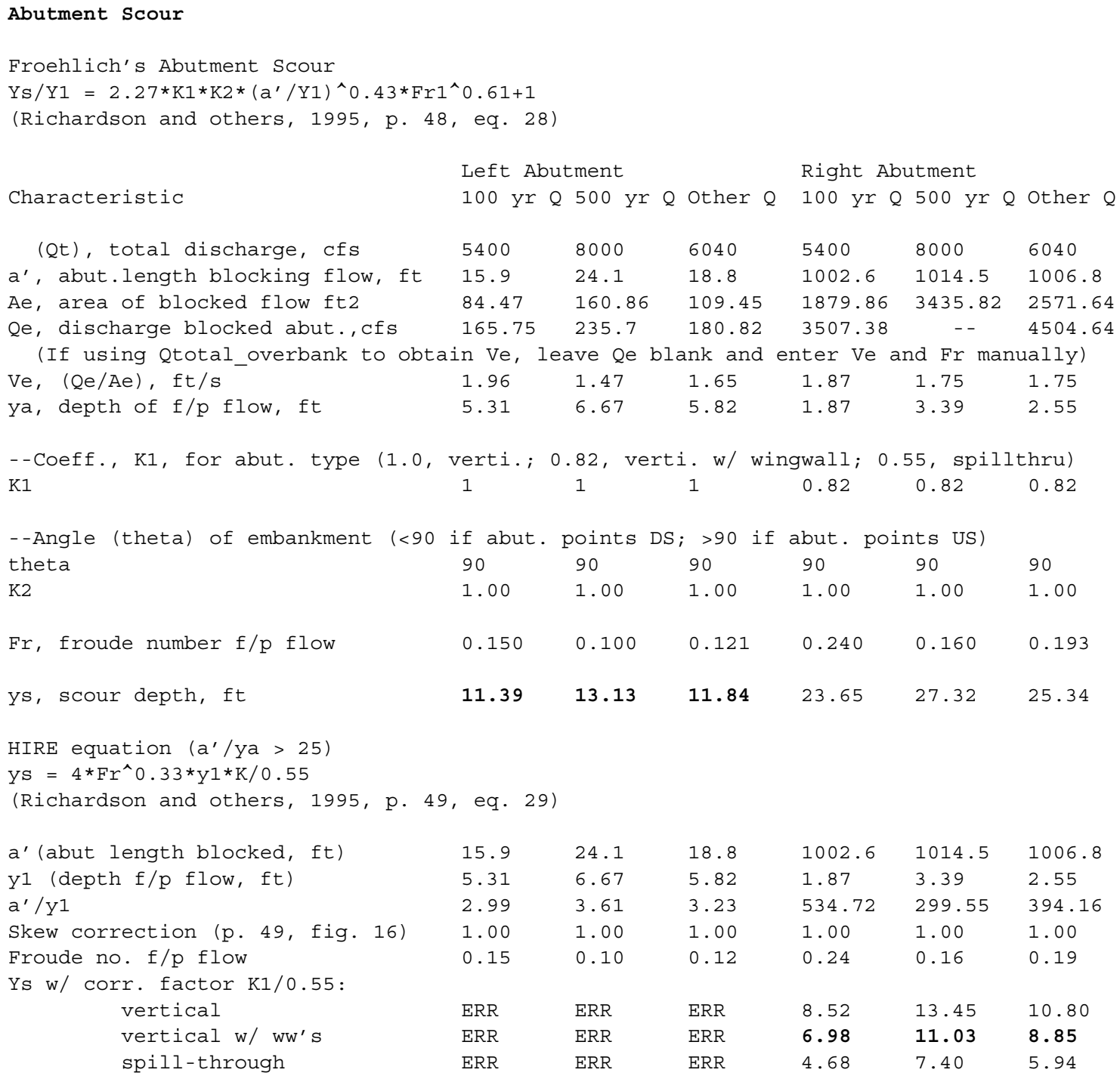

\section{Abutment riprap Sizing}


(Richardson and others, 1995, p112, eq. 81,82)

\begin{tabular}{|c|c|c|c|c|c|c|}
\hline Characteristic & Q100 & Q500 & Other $Q$ & Q100 & Q500 & Other \\
\hline Fr, Froude Number & 0.66 & 0.71 & 0.73 & 0.66 & 0.71 & 0.73 \\
\hline$y$, depth of flow in bridge, ft & 9.36 & 10.57 & 9.47 & 9.36 & 10.57 & 9.47 \\
\hline Median Stone Diameter for riprap & left & atment & & right & atment, & \\
\hline Fr $<=0.8$ (vertical abut.) & 2.52 & 3.29 & 3.12 & 2.52 & 3.29 & 3.12 \\
\hline Fr>0.8 (vertical abut.) & ERR & ERR & ERR & ERR & ERR & ERR \\
\hline
\end{tabular}

